\title{
South Florida Reservoir Embankment Study
}

Jeffrey A. Melby, Elizabeth C. Burg, Darla McVan,

May 2009

and William Henderson 


\section{South Florida Reservoir Embankment Study}

Jeffrey A. Melby, Elizabeth C. Burg, Darla McVan, and William Henderson

Coastal and Hydraulics Laboratory

U.S. Army Engineer Research and Development Center

3909 Halls Ferry Road

Vicksburg, MS 39180-6199

Final report

Approved for public release; distribution is unlimited.

Prepared for U.S. Army Engineer District

701 San Marco Boulevard

Jacksonville, FL 32207-0019 
Abstract: As part of the Comprehensive Everglades Restoration Project (CERP), the Jacksonville District of the U.S. Army Corps of Engineers is designing an impoundment embankment cross-section. The structure is intended to comprise the perimeter of a water supply basin. The conceptual cross-sections feature interior step and berm embankment faces to armor the containment levee, reduce wave overtopping to acceptable levels, and control reflected wave energy. The goal of the study was to develop engineering guidance for optimizing the structure crosssection to provide the minimum structure that met both wave overtopping and wave pressure design criteria. A small-scale physical model study of waves impacting and overtopping the embankment was conducted. A parallel effort was also completed using the Cornell Breaking Waves and Structure (COBRAS) numerical model based on the Reynolds-averaged Navier Stokes (RANS) equations. The COBRAS model was shown to predict both wave overtopping and hydraulic pressures on the embankment well. An empirical equation was developed to predict wave overtopping as a function of structure configuration and wave and water level conditions. The study concluded that the stepped structure with no berm was optimal at reducing overtopping. The structure with continuous steps inhibits turtle egress from the basin. Therefore, guidance is provided for smooth slopes as well as for slopes employing separated blocks for overtopping reduction. The maximum pressures were shown to vary unpredictably with increasing berm width and depth. The maximum pressure was generally higher for the stepped structure without a berm than for the sections with berms. The highest pressures on the embankment appeared to be more a function of the details of the breaking wave interacting with the structure face than the structure geometry. 


\section{Contents}

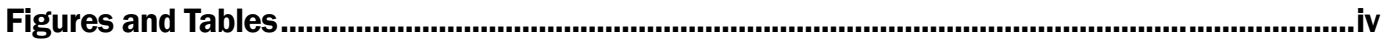

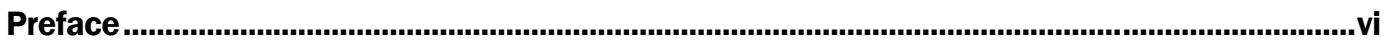

Unit Conversion Factors.........................................................................................................................vii

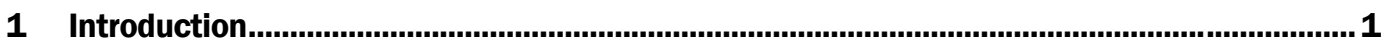

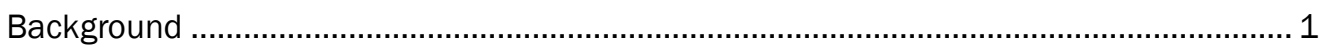

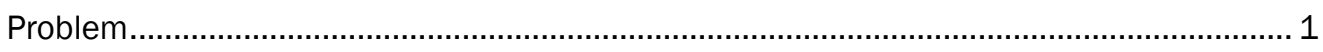

Purpose

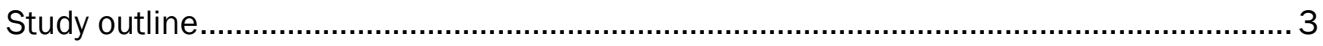

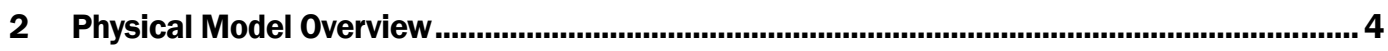

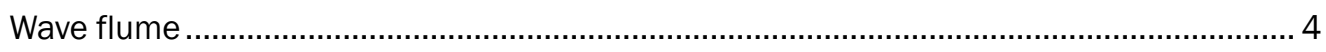

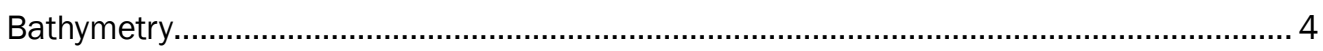

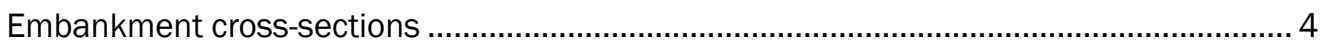

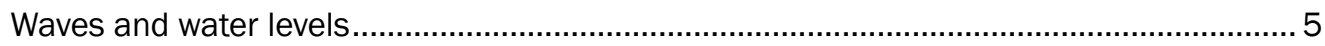

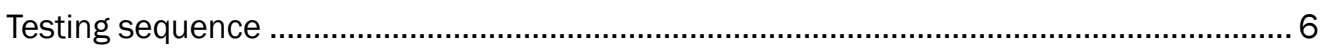

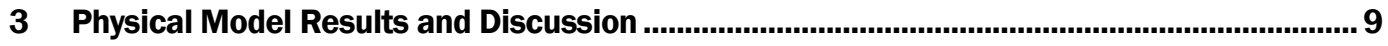

Overtopping and required crest elevation for $13 \mathrm{ft}$ toe water depth .................................... 9

Overtopping and required crest elevation for $19 \mathrm{ft}$ toe water depth................................... 14

Overtopping and required crest elevation for $25 \mathrm{ft}$ toe water depth................................... 17

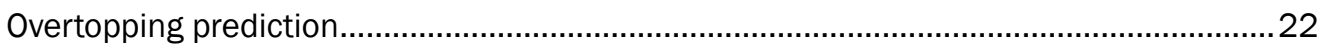

Influence of roughness on crest height .................................................................... 27

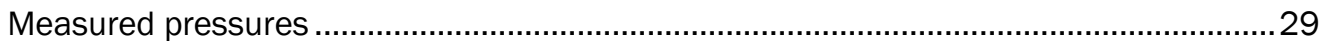

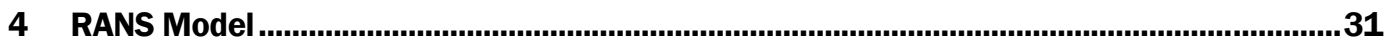

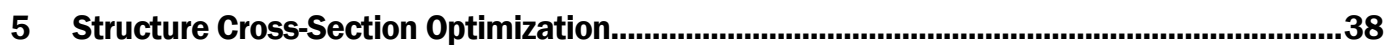

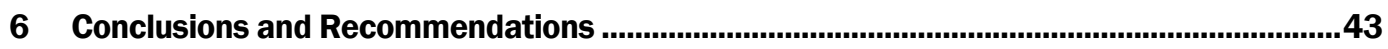

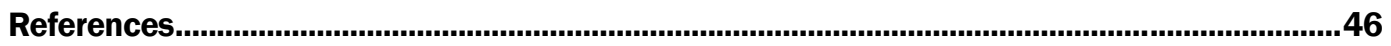

\section{Report Documentation Page}




\section{Figures and Tables}

\section{Figures}

Figure 1. Photograph (left) of step-berm shoreline structure at Hyde Park, Chicago and cross-sectional illustration (right)

Figure 2. Schematic of wave flume (cross-section not to scale) ......................................................... 4

Figure 3. Diagram of testing sequence.................................................................................... 8

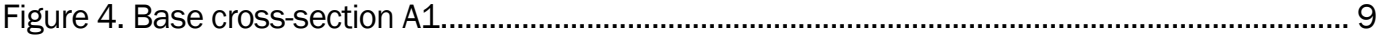

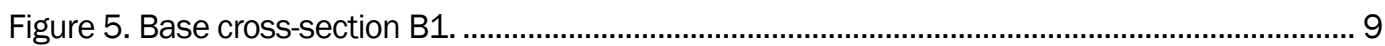

Figure 6. Base cross-section C1. ..................................................................................... 10

Figure 7. Base cross-section D1..................................................................................... 10

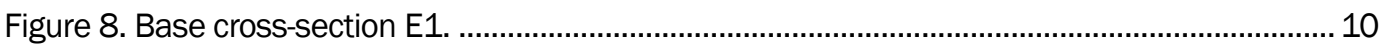

Figure 9. Required freeboard for $25 \mathrm{ft}$ berm width, $13 \mathrm{ft}$ toe depth, and $T_{p}=4.8 \mathrm{sec} . \ldots \ldots \ldots \ldots \ldots \ldots \ldots . . .12$

Figure 10. Required freeboard for $25 \mathrm{ft}$ berm width, $13 \mathrm{ft}$ toe depth, and $T_{p}=6.7 \mathrm{sec} . \ldots \ldots \ldots \ldots \ldots \ldots . . . .12$

Figure 11. Required freeboard for $5 \mathrm{ft}$ berm depth, varying berm widths, $13 \mathrm{ft}$ toe depth,

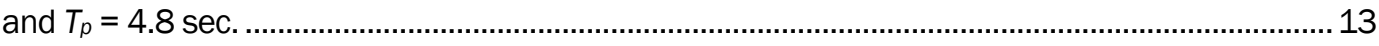

Figure 12. Required freeboard for $5 \mathrm{ft}$ berm depth, varying berm widths, $13 \mathrm{ft}$ toe depth,

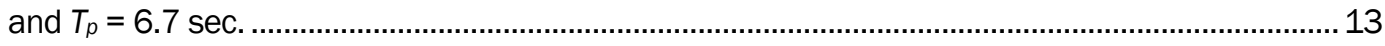

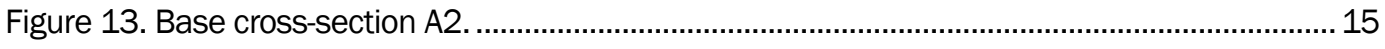

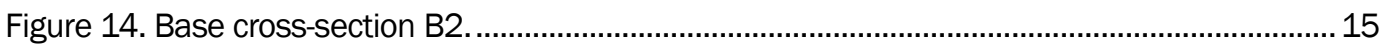

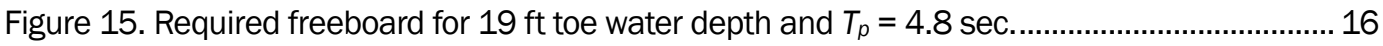

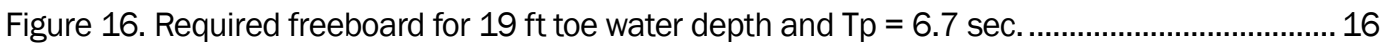

Figure 17. Base cross-section A3.......................................................................................... 17

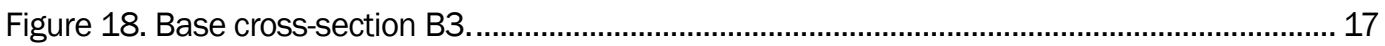

Figure 19. Base cross-section C3.................................................................................... 17

Figure 20. Base cross-section D3...................................................................................... 18

Figure 21. Base cross-section E3...................................................................................... 18

Figure 22. Required freeboard for $25 \mathrm{ft}$ berm width at varying depths, $25 \mathrm{ft}$ toe depth,

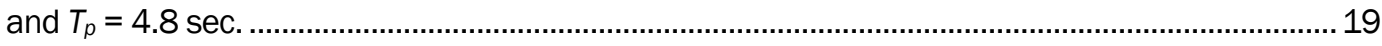

Figure 23. Required freeboard for $25 \mathrm{ft}$ berm width at varying depths, $25 \mathrm{ft}$ toe depth, and $T_{p}=6.7 \mathrm{sec}$

Figure 24. Required freeboard for $5 \mathrm{ft}$ berm depth with varying berm widths, $25 \mathrm{ft}$ toe depth, and $T_{p}=4.8 \mathrm{sec}$.

Figure 25. Required freeboard for $5 \mathrm{ft}$ berm depth with varying berm widths, $25 \mathrm{ft}$ toe depth, and $T_{p}=6.7 \mathrm{sec}$.

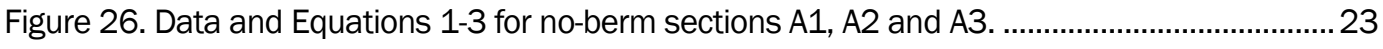

Figure 27. Normalized overtopping rate as a function of relative freeboard for all data sets........... 25

Figure 28. Normalized overtopping rate as a function of relative freeboard for Sections $A$ (no berm) and B ( $25 \mathrm{ft}$ wide berm). 
Figure 29. Normalized overtopping rate as a function of relative freeboard for Section C (40 ft wide berm).

Figure 30. Normalized overtopping rate as a function of relative freeboard for Sections $D$ and $\mathrm{E}$ (25 ft wide berm).

Figure 31. Normalized overtopping rate as a function of relative freeboard for Sections A1, $A 2$, and $A 3$ with $\gamma_{r}=1$ (smooth slope).

Figure 32. Illustrative photograph showing the use of discontinuous roughness elements (Photo Courtesy of Prof. Holger Schüttrumpf).

Figure 33. Maximum required freeboard as a function of roughness coefficient for $\mathrm{HmO}=8 \mathrm{ft}$.

Figure 34. Base cross-section D1 with pressure transducer s installed. .........................................29

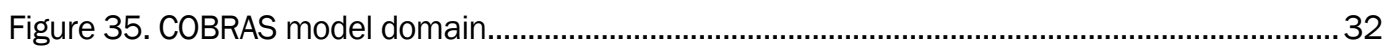

Figure 36. Wave overtopping comparison between COBRAS model and physical model measurements. 33

Figure 37. Pressure head time series from physical model and COBRAS for section A2.

Figure 38. Pressure distributions from RANS model corresponding to maximum pressure tests for sections A1, B1, C1, D1, and E1 35

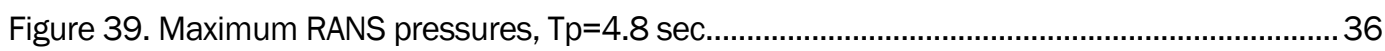

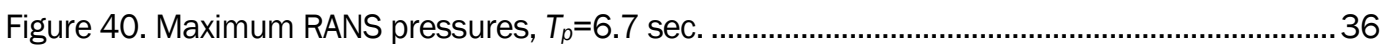

Figure 41. Contribution of berm crest width to slab volume for various berm depths and toe water depths

Figure 42. Contribution of step and seaward slope width to slab volume for various berm depths and toe water depths.

Figure 43. Contribution of step and slope section width to slab volume for various berm

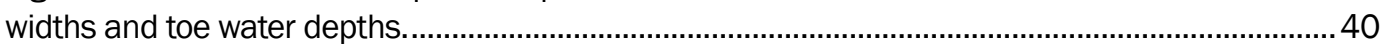

Figure 44. Slab volume as a function of normalized berm depth.................................................... 41

Figure 45. Slab volume as a function of normalized crest freeboard............................................... 41

\section{Tables}

Table 1. Cross-section characteristics. 5

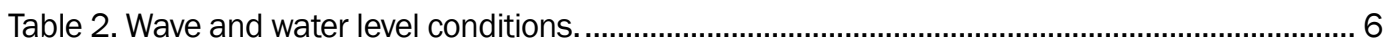

Table 3. Wave and water level conditions by section.................................................................... 7

Table 4. Freeboard required to achieve target overtopping rate for $13 \mathrm{ft}$ toe depth. ........................ 11

Table 5. Total structure width for maximum freeboard conditions with $13 \mathrm{ft}$ toe depth..................... 14

Table 6. Total structure height for maximum freeboard conditions with $13 \mathrm{ft}$ toe depth................... 14

Table 7. Freeboard, width, and height for maximum freeboard conditions for $19 \mathrm{ft}$ toe water depth.

Table 8. Freeboard required to achieve target overtopping rate for $25 \mathrm{ft}$ toe water depth............... 18

Table 9. Total structure width for maximum freeboard conditions and $25 \mathrm{ft}$ toe depth. ................... 21

Table 10. Total structure height for maximum freeboard conditions and $25 \mathrm{ft}$ toe depth................ 21

Table 11. Measured maximum pressure in feet of head. .................................................................30 


\section{Preface}

The study summarized in this report was conducted at the request of the Jacksonville District (SAJ), USACE. Lori Hadley was the primary engineering point of contact at SAJ and Robert Tucker was the Program Manager at SAJ. The study was funded by SAJ and conducted at the Engineer Research and Development Center (ERDC), Coastal and Hydraulics Laboratory (CHL), Vicksburg, MS, during the period June 2007 - April 2009.

This report was prepared by Dr. Jeffrey A. Melby, Elizabeth Burg, and William Henderson, Harbors, Entrances, and Structures (HES) Branch, CHL, and Darla McVan, Hydrologic Systems Branch, CHL. Hugh Acuff, HES Branch, and Timothy Nisley, Information Technology Laboratory, ERDC, provided significant assistance for the laboratory component.

Patrick Lynett, Texas A\&M University, and Jeffrey Hensley, Information Technology Laboratory, provided valuable assistance with the Cornell Breaking Waves and Structure (COBRAS) numerical model. Work at CHL was performed under the general supervision of Jackie Pettway, Chief, HES Branch, and Dr. Rose Kress, Chief, Navigation Division.

Dr. William D. Martin was Deputy Director, CHL, and Thomas W. Richardson was Director, CHL.

COL Gary E. Johnston was Commander and Executive Director of ERDC. Dr. James R. Houston was ERDC Director. 


\section{Unit Conversion Factors}

A sponsor and stakeholders requirement for this study was the use of English Customary units of measurement. Most measurements and calculations were done in SI units and then converted to English Customary. The following table can be used to convert back to SI units.

\begin{tabular}{|l|l|l|}
\hline Multiply & \multicolumn{1}{|c|}{ By } & To Obtain \\
\hline feet & 0.3048 & meters \\
\hline cubic feet & 0.02831685 & cubic meters \\
\hline pounds (force) & 4.448222 & newtons \\
\hline square feet & 0.09290304 & square meters \\
\hline pounds per square inches & 6.894757 & kilo-newtons per square meter \\
\hline
\end{tabular}




\section{Introduction}

\section{Background}

As part of the Comprehensive Everglades Restoration Project (CERP), the Jacksonville District of the U.S. Army Corps of Engineers is designing an impoundment embankment cross-section. The structure is intended to comprise the perimeter of a water supply basin. The conceptual crosssections feature interior step and berm embankment faces to armor the containment levee, reduce wave overtopping to acceptable levels, and control reflected wave energy (Figure 1).

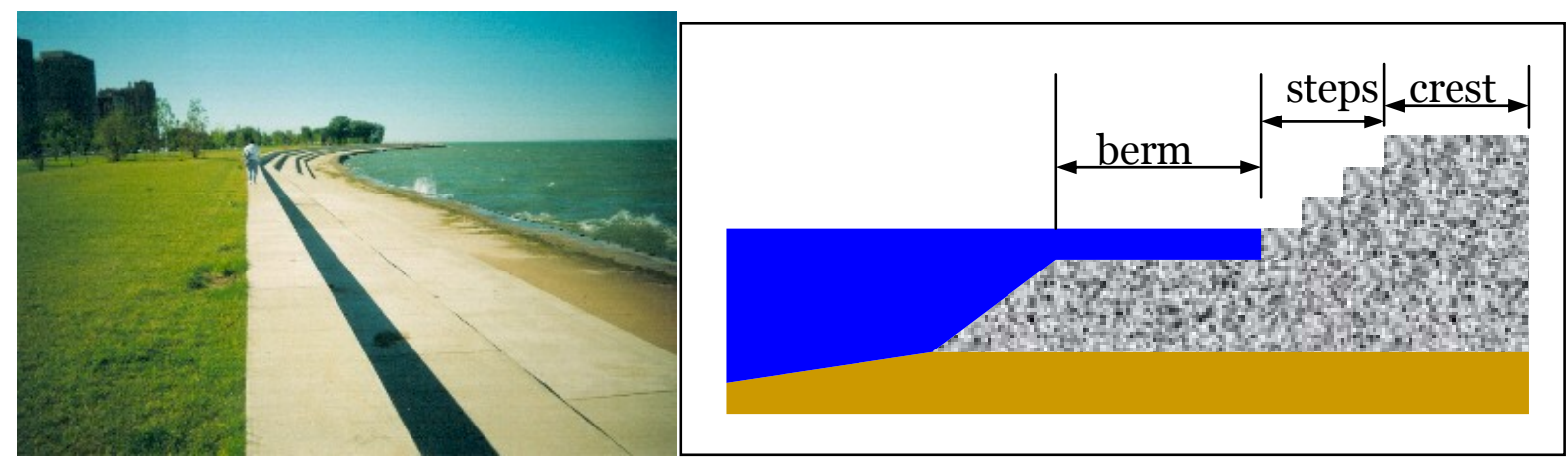

Figure 1. Photograph (left) of step-berm shoreline structure at Hyde Park, Chicago and crosssectional illustration (right).

\section{Problem}

Step-berm shoreline structures are widely used. This class of structure typically consists of a concrete slab sloping or stepped from a submerged toe up to a horizontal berm above or near the high water level with steps above that progressing up to a flat crest. The concrete slab is usually cast directly on a membrane-covered prepared fill. Little specific guidance exists for step-berm concrete embankments exposed to wave attack. Wave runup and overtopping empirical equations (e.g., CEM 2002, EurOtop 2007) provide crude guidance for determining berm and overall structure geometry. However, existing runup and overtopping equations are intended to be universal, covering all sloping structure types. There is no specific guidance for structures with steps. As such, existing empirical equations do not provide the accuracy and level of detail required to optimize the geometry for step-berm structures. Further, wave breaking pressures on the seaward face can be extreme for certain section 
geometries resulting in increased section costs. No guidance exists for predicting wave pressures on the seaward face. Volumetric optimization must consider the crest height, step-berm geometry, and the extreme wave pressures. Modern phase-resolving wave transformation models that are capable of modeling wave overtopping include those based on the Boussinesq equations and Reynolds-averaged Navier Stokes (RANS) equations, among others. Existing Boussinesq models may be useful for modeling wave overtopping on relatively smooth gentle-sloped embankments but generally are not sufficiently accurate for relatively steep-fronted stepped structures without specific calibration against a physical model or prototype data. On the other hand, RANS models are vary capable of solving the flow around these structures and are being introduced into the design of coastal structure problems (Lin and Liu 1998, Hsu et al 1998). However, RANS models present significant computational demand that still limit their use and they have not been validated for these complex structure cross-sections.

\section{Purpose}

The purpose of this study was to develop general criteria and tools for design and optimization of the impoundment embankment cross-section for the CERP. The step-berm roller-compacted concrete structure comprising the water supply basin perimeter will armor the impervious containment structure, limit wave overtopping, and dissipate wave energy. For select structure cross-sections, the freeboard required to achieve the desired overtopping rate of $0.005 \mathrm{ft} 3 / \mathrm{sec} / \mathrm{ft}$ is determined. Generalized predictive wave overtopping equations are developed to allow optimization of the structure cross-section. In addition, the maximum wave-induced pressures and associated spatial pressure distributions along the structure face are quantified. The combination of these efforts provides the fundamental information required to develop the optimal structure crosssection for function and cost. 


\section{Study outline}

The study included two basic parts: two-dimensional wave flume smallscale physical model study and RANS numerical model study. The physical model was intended to validate the numerical model with the numerical model used to provide guidance for a wider range of conditions than could be completed in the physical model. However, limitations of the RANS model discovered during the course of the study demanded more of a hybrid modeling solution. 


\section{Physical Model Overview}

\section{Wave flume}

The small-scale physical model study was conducted at the U.S. Army Engineer Research and Development Center's Coastal and Hydraulics Laboratory in Vicksburg, MS. All tests were conducted in a glass-walled flume, $150 \mathrm{ft}$ long by $3.0 \mathrm{ft}$ deep by $1.5 \mathrm{ft}$ wide equipped with a computer controlled, electro-hydraulic piston type wave generator. Figure 2 shows a schematic drawing of the flume.

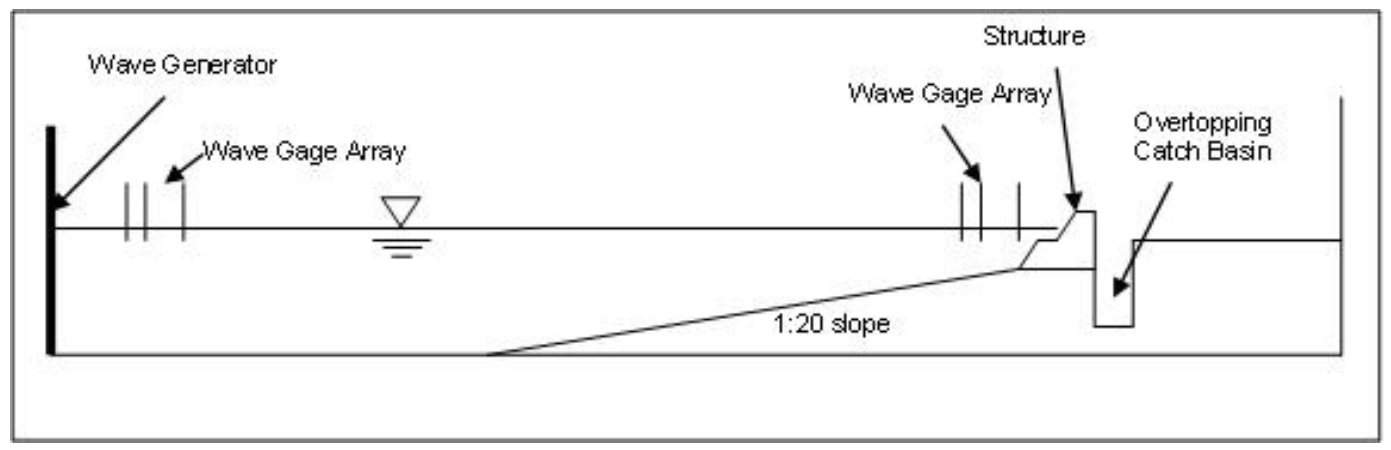

Figure 2. Schematic of wave flume (cross-section not to scale).

The model was built at an undistorted linear scale of 1:20 (model: prototype), which was determined to be the largest scale for which the wave generator could reproduce the desired wave spectra. Hydrodynamics were modeled based on Froude similitude. All dimensions and results in this report are presented in prototype scale, with all elevations referenced to still water level (swl) unless otherwise noted.

\section{Bathymetry}

The prototype bathymetry seaward of the structure is expected to be flat, but a 1:20 (V: H) slope was placed in the flume in order to achieve the desired wave heights at the structure. The bathymetry sloped seaward at 1:20 for $30 \mathrm{ft}$ (model scale) from the structure toe.

\section{Embankment cross-sections}

Cross-sections were constructed of marine plywood and high density foam. The basic embankment design consisted of a 1:3 (V:H) slope from the structure toe up to a variable-width berm then up a stair-stepped slope 
to a $14.0 \mathrm{ft}$ wide crest. The steps were $1 \mathrm{ft}$ high by $3 \mathrm{ft}$ wide. The final structure crest elevation was dependent on the desired overtopping rate of $0.005 \mathrm{ft} 3 / \mathrm{sec} / \mathrm{ft}$, which was in turn dependent on wave height, wave period, water level and structure geometry. The cross-sections were broken down into five classes based on systematic variations in berm width and berm or toe depth. Table 1 provides the class characteristics for each base cross-section.

Table 1. Cross-section characteristics.

\begin{tabular}{|l|l|l|}
\hline $\begin{array}{l}\text { Structure Class } \\
\text { Name }\end{array}$ & Berm Width, ft & $\begin{array}{l}\text { Berm or First Step } \\
\text { Depth Below swl, ft }\end{array}$ \\
\hline A & 0.0 & 3.0 \\
\hline B & 25.0 & 5.0 \\
\hline C & 40.0 & 5.0 \\
\hline D & 25.0 & 0.0 \\
\hline E & 25.0 & 2.5 \\
\hline
\end{tabular}

\section{Waves and water levels}

Overtopping rates are dependent on water level, incident wave height, and wave period. The Jacksonville District specified three water levels, three wave heights, and two wave periods for testing (Table 2). All wave and water level conditions are specified at the toe of the structure. The wave height is the incident spectral significant wave height, $H_{m 0}=\left(4 m_{0}\right)^{1 / 2}$, where $m_{\mathrm{o}}$ is the zeroth moment of the incident wave energy density spectrum $\left(m_{n}=\int f^{n} S(f) d f\right)$. The wave period is the peak wave period, $T_{p}$, corresponding to the inverse of the peak frequency of the incident wave spectrum. Waves were generated using the Joint North Sea Wave Project Spectrum (Hasselmann et al. 1973) with a spectral spreading coefficient of $\gamma=3.3$.

Water surface elevations were sampled near the wave generator and near the structure toe using capacitance-type wave gages. The gages were configured in two 3-gage arrays to allow resolution of incident and reflected wave spectra. The gage spacing was $0.5 \mathrm{ft}$ and $2.5 \mathrm{ft}$. The sampling rate was $20 \mathrm{~Hz}$ or, if pressures were also measured, $100 \mathrm{~Hz}$. The measured wave spectra were band passed between roughly $0.3 \mathrm{~Hz}$ and 
2.0 $\mathrm{Hz}$ in order to limit reflection analysis to coherent range. Each model flume run was $15 \mathrm{~min}$ in duration.

Table 2. Wave and water level conditions.

\begin{tabular}{|l|l|l|l|}
\hline $\begin{array}{l}\text { Water Level } \\
\text { ID }\end{array}$ & Toe Water Depth, $\mathrm{ft}$ & $\begin{array}{l}\text { Peak Wave } \\
\text { Period } T_{p}, \text { sec }\end{array}$ & $\begin{array}{l}\text { Nearshore Incident } \\
\text { Wave Height } H_{m 0}, \mathrm{ft}\end{array}$ \\
\hline 1 & 13.0 & 4.8 & 5.0 \\
\cline { 3 - 4 } & & & 6.5 \\
\cline { 3 - 4 } & & & 8.0 \\
\cline { 3 - 4 } & & 6.7 & 5.0 \\
\cline { 3 - 4 } & & & 6.5 \\
\hline 2 & & & 8.0 \\
\hline 3 & 19.0 & Same as above \\
\hline
\end{tabular}

\section{Testing sequence}

Each class of structure cross-section was tested at the three water levels, but in order to keep the berm depth consistent between water levels, the length of slope from the structure toe to the berm changed between water levels. This resulted in a unique cross-section being tested for each water level. For example, compare the "B" class cross-section between the three water levels: at $13 \mathrm{ft}$ toe depth, $24 \mathrm{ft}$ of 1:3 slope is required for the berm to be at $5 \mathrm{ft}$ depth; at toe depth $19 \mathrm{ft}, 42 \mathrm{ft}$ of 1:3 slope is required; at toe depth $25 \mathrm{ft}, 60 \mathrm{ft}$ of 1:3 slope is required. This results in the berm elevation being $8 \mathrm{ft}$ from toe at toe depth $13 \mathrm{ft}$, but $14 \mathrm{ft}$ at toe depth $19 \mathrm{ft}$, and $20 \mathrm{ft}$ at toe depth $25 \mathrm{ft}$.

With five classes of cross-sections and three water levels there are a total of 15 base cross-sections for testing. Due to time constraints it was decided that only the $13 \mathrm{ft}$ and $25 \mathrm{ft}$ water depths would be tested for all five classes, with only the "A" and "B" classes being tested at the $19 \mathrm{ft}$ toe depths. This resulted in a total of 12 base cross-sections as summarized in Table 3. The Section naming convention in Table 3 combines the water level numbering scheme with the cross-section label. 
In order to limit the overtopping rate to the target level, steps were added to each base section to increase the crest elevation. The steps measured $1 \mathrm{ft}$ high by $3 \mathrm{ft}$ wide, prototype. A diagram illustrating the typical testing sequence is shown in Figure 3. This sequence was followed for both wave periods $\left(T_{p}=4.8\right.$ and $\left.6.7 \mathrm{sec}\right)$. Overtopping was captured in a water-tight metal catch basin placed directly leeward of the structure and was measured volumetrically after each test. The overtopped water was circulated back into the wave flume throughout the test to prevent lowering of the still water level in the flume. With each step added to a cross-section, the total structure width was increased in order to maintain the crest width at $14 \mathrm{ft}$.

Table 3. Wave and water level conditions by section.

\begin{tabular}{|l|l|l|l|}
\hline Section & Berm Width, ft & $\begin{array}{l}\text { Toe Water } \\
\text { Depth, ft }\end{array}$ & $\begin{array}{l}\text { Berm or First } \\
\text { Step Depth, ft }\end{array}$ \\
\hline A1 & 0 & 13 & 3 \\
\hline A2 & 0 & 19 & 3 \\
\hline A3 & 0 & 25 & 3 \\
\hline B1 & 25 & 13 & 5 \\
\hline B2 & 25 & 19 & 5 \\
\hline B3 & 25 & 25 & 5 \\
\hline C1 & 40 & 13 & 5 \\
\hline C3 & 40 & 25 & 5 \\
\hline D1 & 25 & 13 & 0 \\
\hline D3 & 25 & 25 & 0 \\
\hline E1 & 25 & 13 & 2.5 \\
\hline E3 & 25 & 25 & 2.5 \\
\hline
\end{tabular}




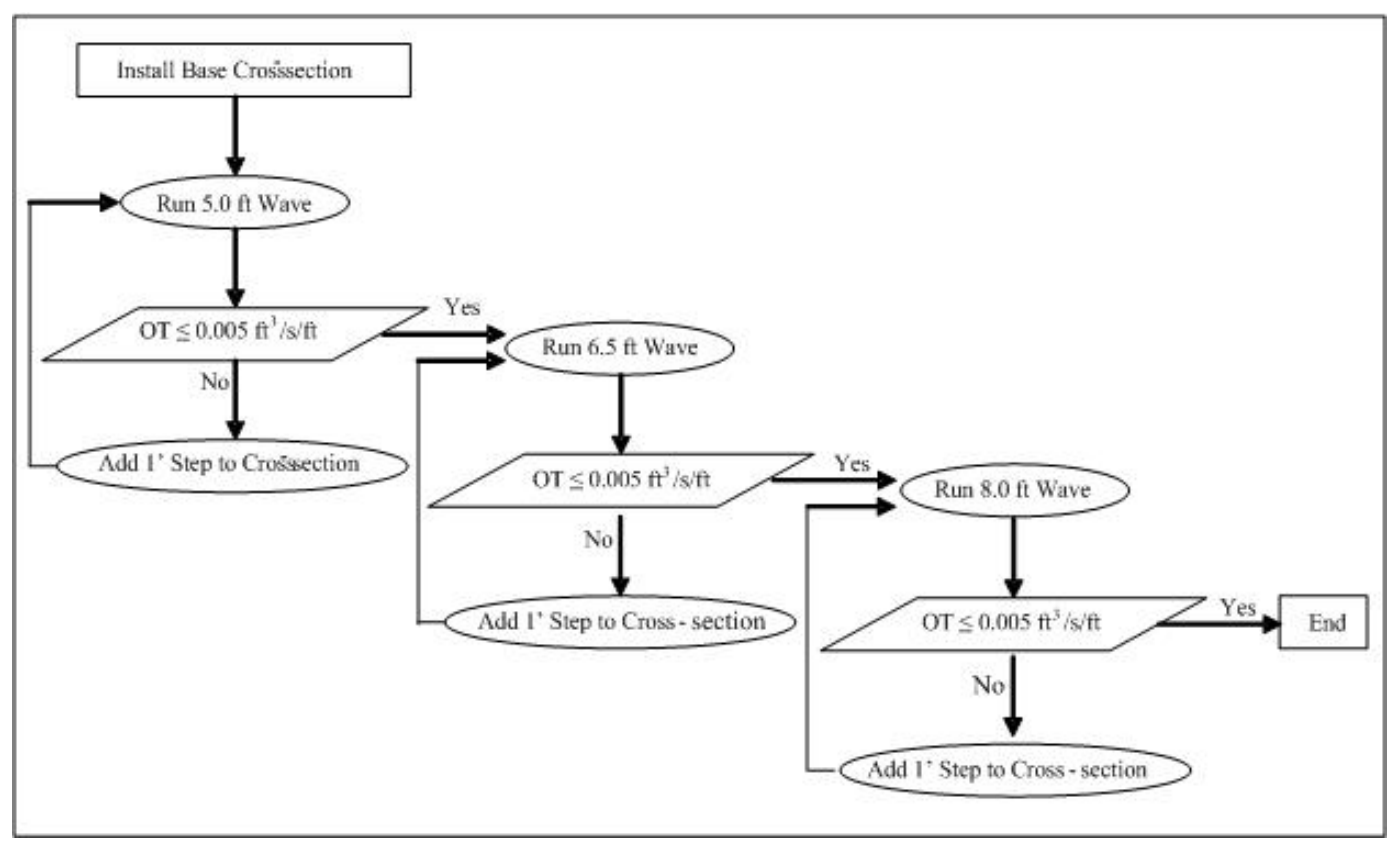

Figure 3. Diagram of testing sequence. 


\section{Physical Model Results and Discussion}

\section{Overtopping and required crest elevation for $13 \mathrm{ft}$ toe water depth}

Each cross-section was tested at $13 \mathrm{ft}$ toe water depth. Figures 4-8 show base cross-sections for this water depth. "Base cross-section" refers to the initial cross-section to which steps were added until the overtopping goal was achieved. In these figures, $R_{c}$ refers to the freeboard, the distance from still water level to structure crest.

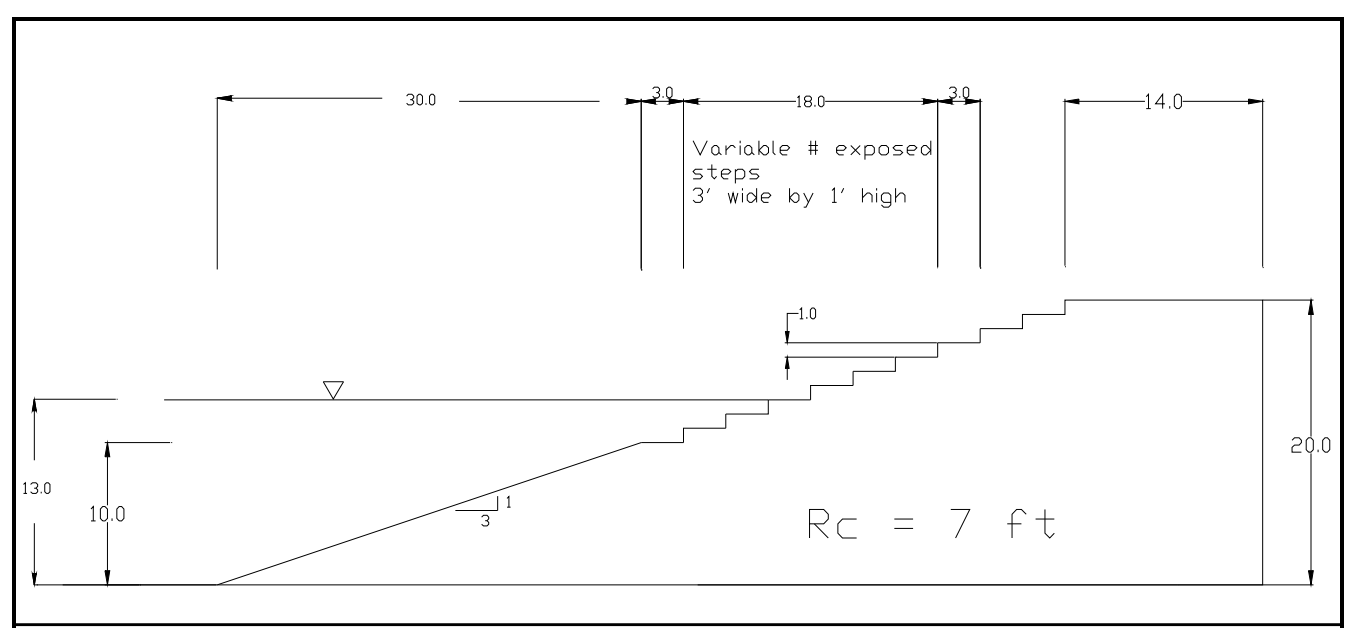

Figure 4. Base cross-section A1.

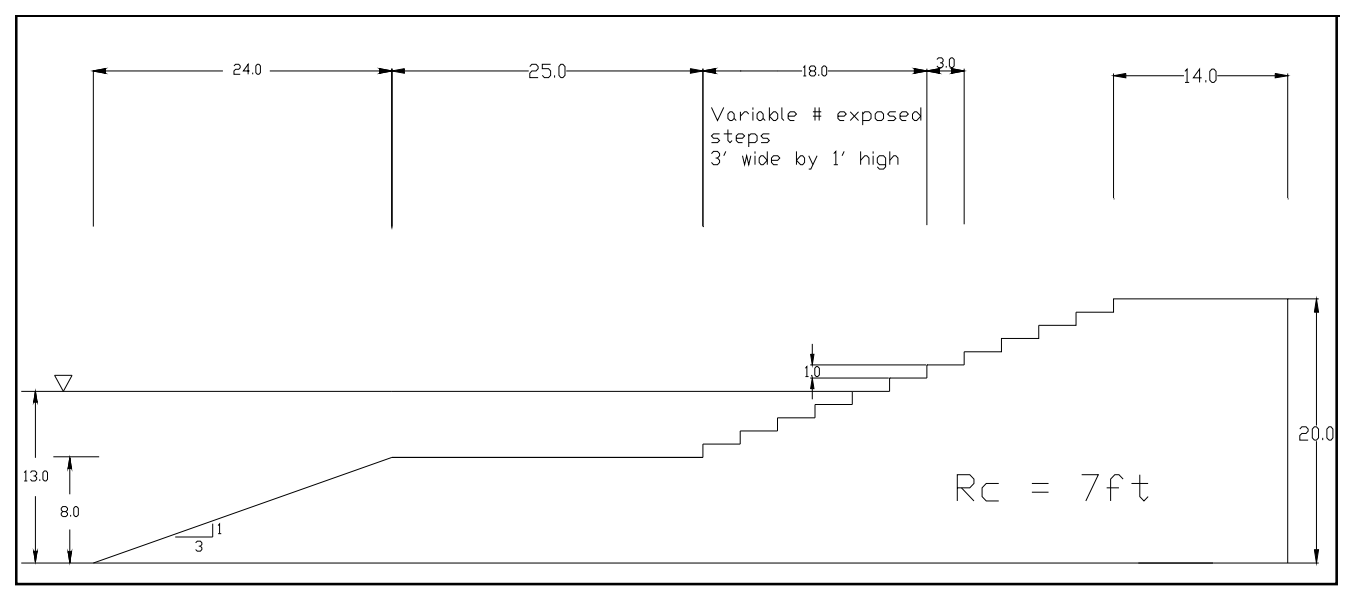

Figure 5. Base cross-section B1. 


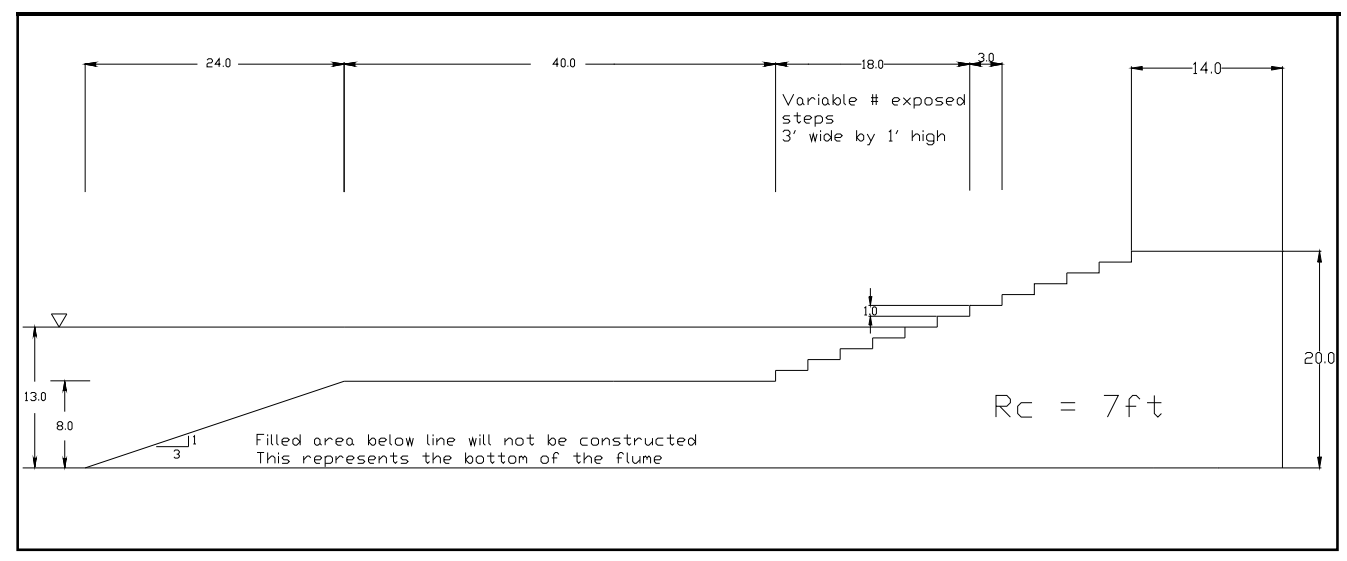

Figure 6. Base cross-section C1.

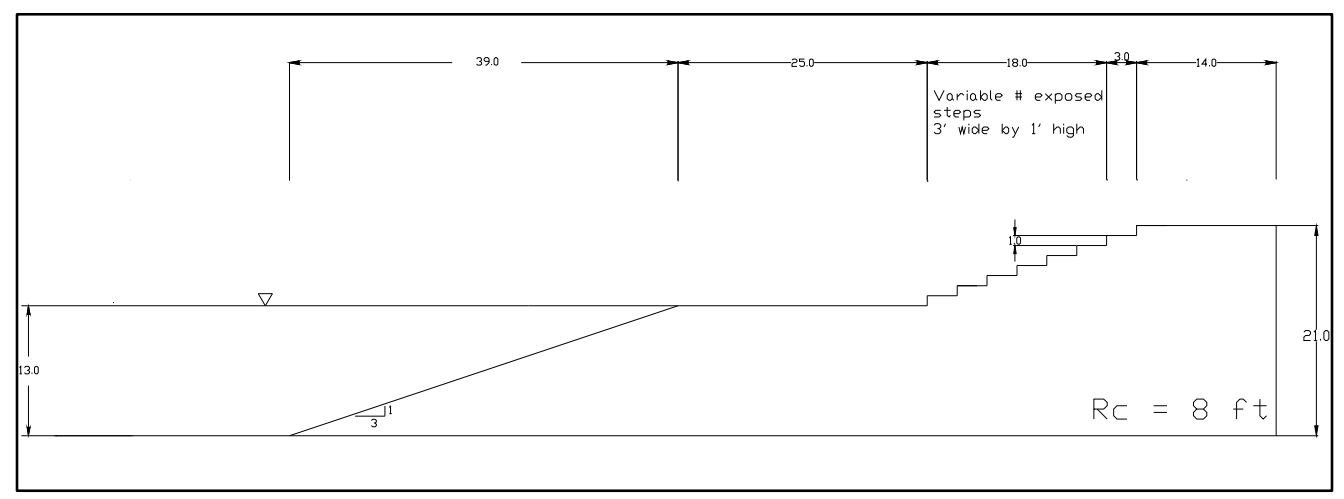

Figure 7. Base cross-section D1.

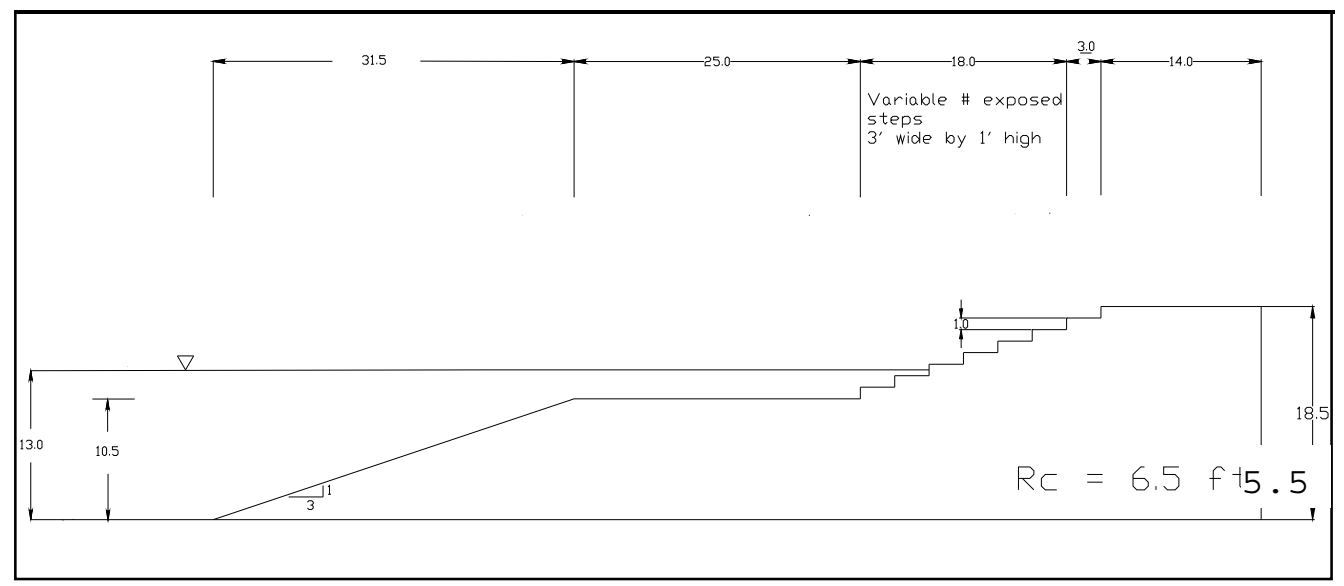

Figure 8. Base cross-section E1. 
Table 4. Freeboard required to achieve target overtopping rate for $13 \mathrm{ft}$ toe depth.

\begin{tabular}{|c|c|c|c|c|c|c|}
\hline \multirow{2}{*}{$\begin{array}{l}\text { Peak Wave } \\
\text { Period } T_{p} \text {, } \\
\text { sec }\end{array}$} & \multirow{2}{*}{$\begin{array}{l}\text { Nearshore } \\
\text { Incident Wave } \\
\text { Height } H_{m 0}, \mathrm{ft}\end{array}$} & \multicolumn{5}{|c|}{ Freeboard $R_{c}, \mathrm{ft}$} \\
\hline & & $\mathrm{A} 1$ & B1 & C1 & D1 & E1 \\
\hline \multirow[t]{3}{*}{4.8} & 5.0 & 8.0 & 6.0 & 5.0 & 8.0 & 6.5 \\
\hline & 6.5 & 11.0 & 8.0 & 7.0 & 8.0 & 6.5 \\
\hline & 8.0 & 12.0 & 10.0 & 8.0 & 11.0 & 7.5 \\
\hline \multirow[t]{3}{*}{6.7} & 5.0 & 11.0 & 8.0 & 7.0 & 8.0 & 6.5 \\
\hline & 6.5 & 12.0 & 10.0 & 9.0 & 11.0 & 8.5 \\
\hline & 8.0 & 15.0 & 13.0 & 13.0 & 13.0 & 12.5 \\
\hline
\end{tabular}

Table 4 summarizes the freeboard required to achieve the target overtopping rate for toe water depth $13 \mathrm{ft}$. Berm effectiveness at reducing required freeboard is illustrated by observing two sets of results: 1 . varied crest elevation for three cross-sections with $25 \mathrm{ft}$ berm (classes B, D, and E), and 2. varied crest elevation for $25 \mathrm{ft}$ and $40 \mathrm{ft}$ wide berm classes (B and C).

Figures 9 and 10 show the freeboard required for all classes with $25 \mathrm{ft}$ berm width and $13 \mathrm{ft}$ toe depth, for $T_{p}=4.8$ and $6.7 \mathrm{sec}$, respectively. Based on these results, cross-section E1 was the most effective for $H_{m 0}=6.5 \mathrm{ft}$ and $H_{m 0}=8.0 \mathrm{ft}$, for the shorter wave period, and was the most effective for all three wave heights at the longer period. For $H_{m 0}=5.0 \mathrm{ft}$ at the shorter period, cross-section B1 required a freeboard $0.5 \mathrm{ft}$ lower than E1. So the $25 \mathrm{ft}$ berm positioned $2.5 \mathrm{ft}$ below the still water level performed better than the deeper and shallower berm.

Figures 11 and 12 compare the freeboard required for $5 \mathrm{ft}$ berm depth with $T_{p}=4.8$ and $6.7 \mathrm{sec}$, respectively. For nearly all cases, the $40 \mathrm{ft}$ wide berm required less freeboard than the $25 \mathrm{ft}$ wide berm. The exception was $H_{m o}=$ $8.0 \mathrm{ft}$ with $T_{p}=6.7 \mathrm{sec}$, where the same amount of freeboard was required for both berm widths. Based on observations from this series, the $40 \mathrm{ft}$ wide berm at $2.5 \mathrm{ft}$ depth was optimal in producing the lowest crest height. 


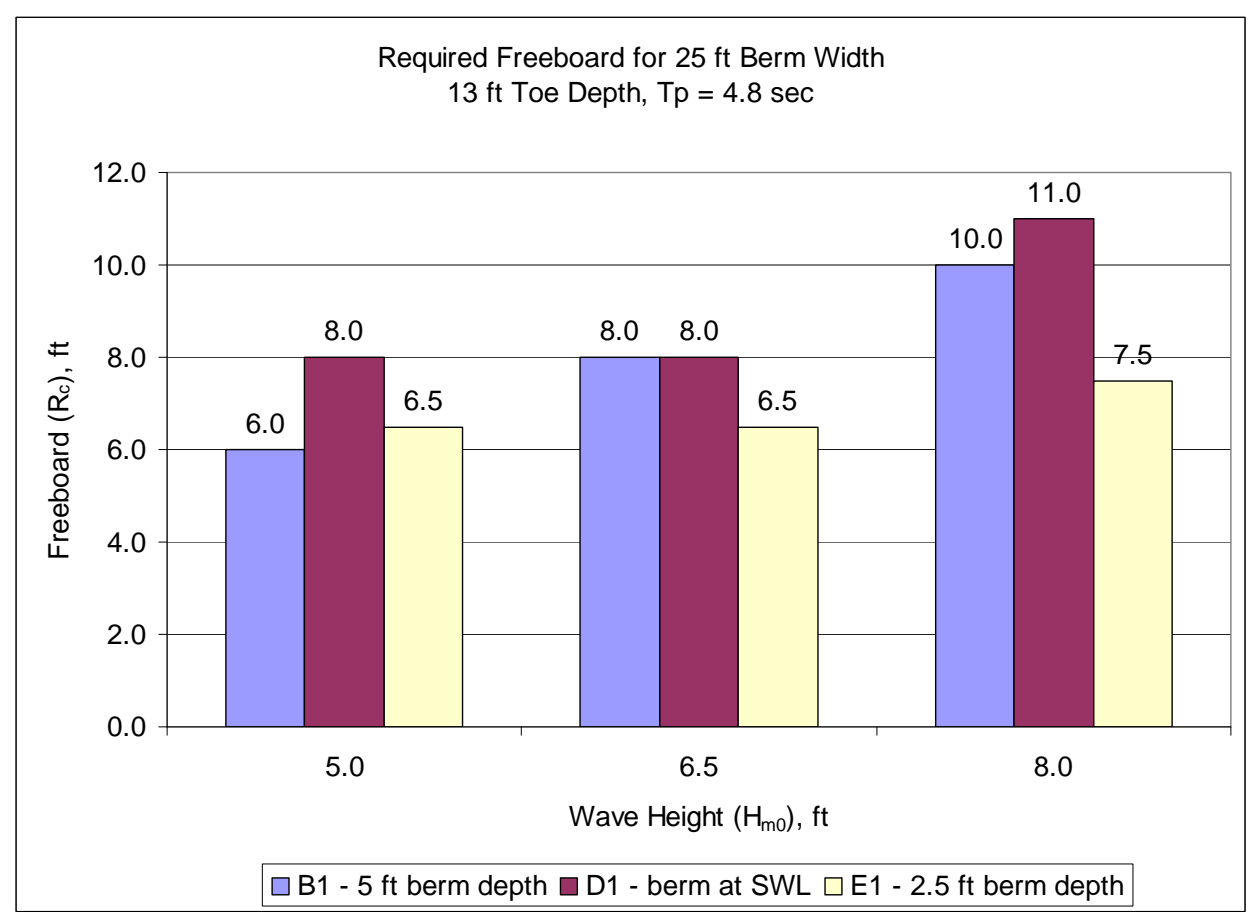

Figure 9. Required freeboard for $25 \mathrm{ft}$ berm width, $13 \mathrm{ft}$ toe depth, and $T_{p}=4.8 \mathrm{sec}$.

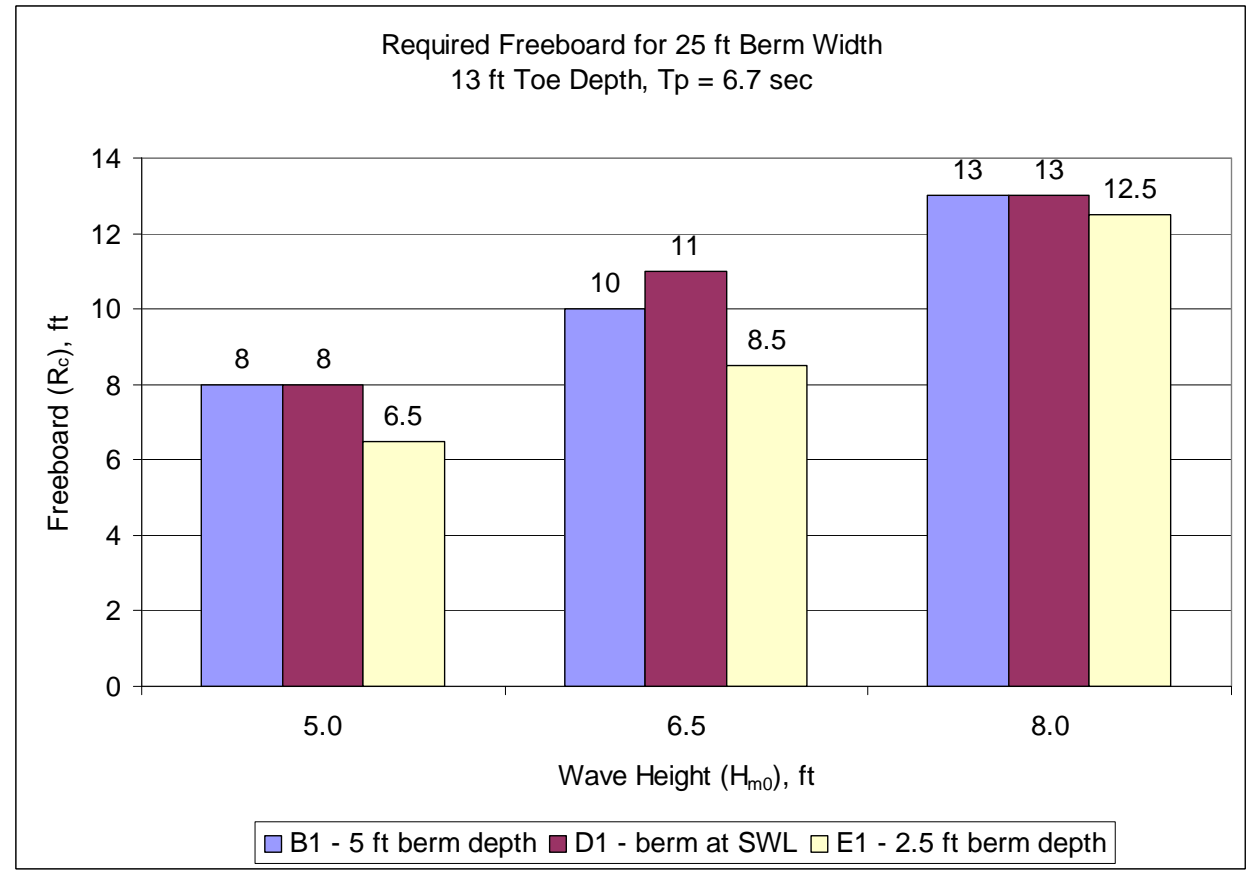

Figure 10. Required freeboard for $25 \mathrm{ft}$ berm width, $13 \mathrm{ft}$ toe depth, and $T_{p}=6.7 \mathrm{sec}$. 


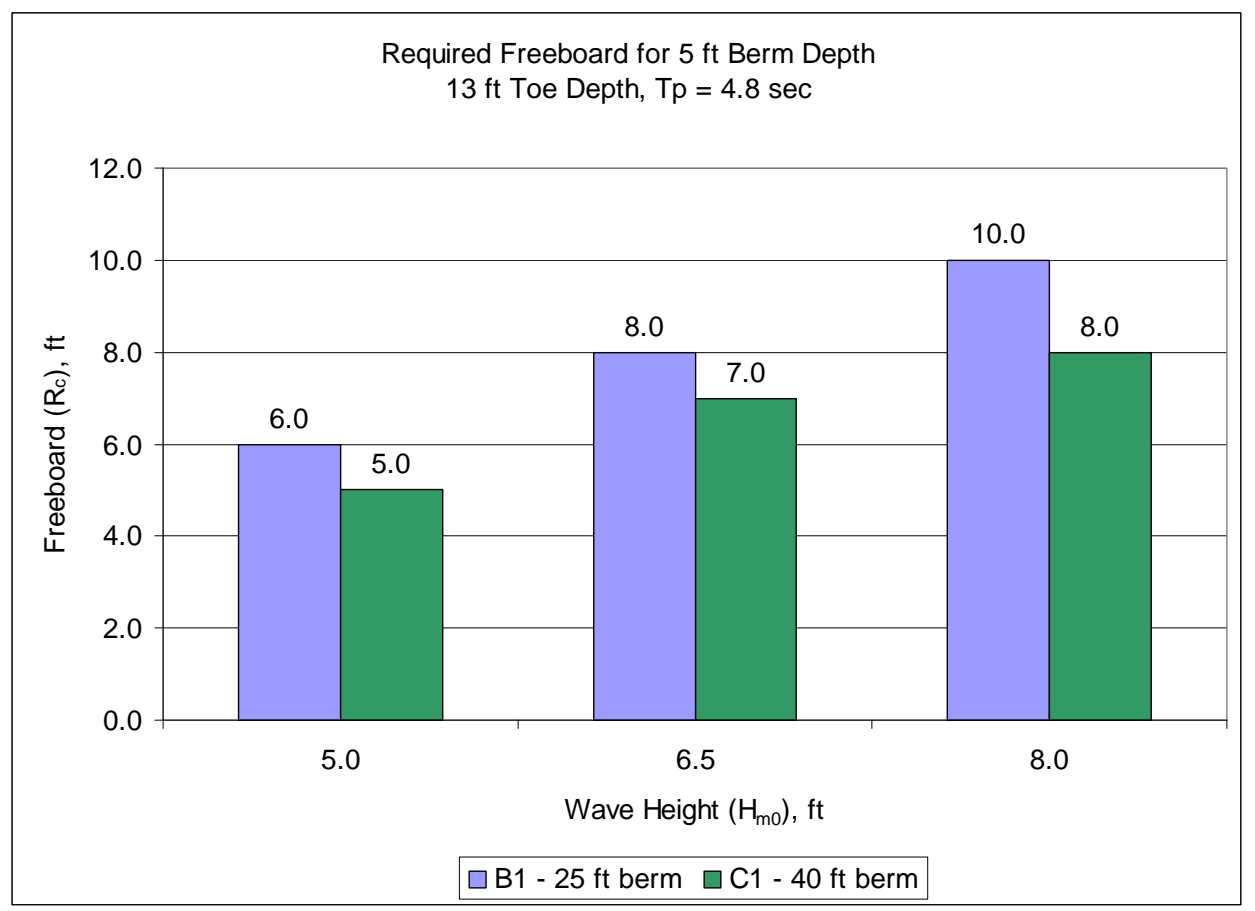

Figure 11. Required freeboard for $5 \mathrm{ft}$ berm depth, varying berm widths, $13 \mathrm{ft}$ toe depth, and $T_{p}=4.8 \mathrm{sec}$.

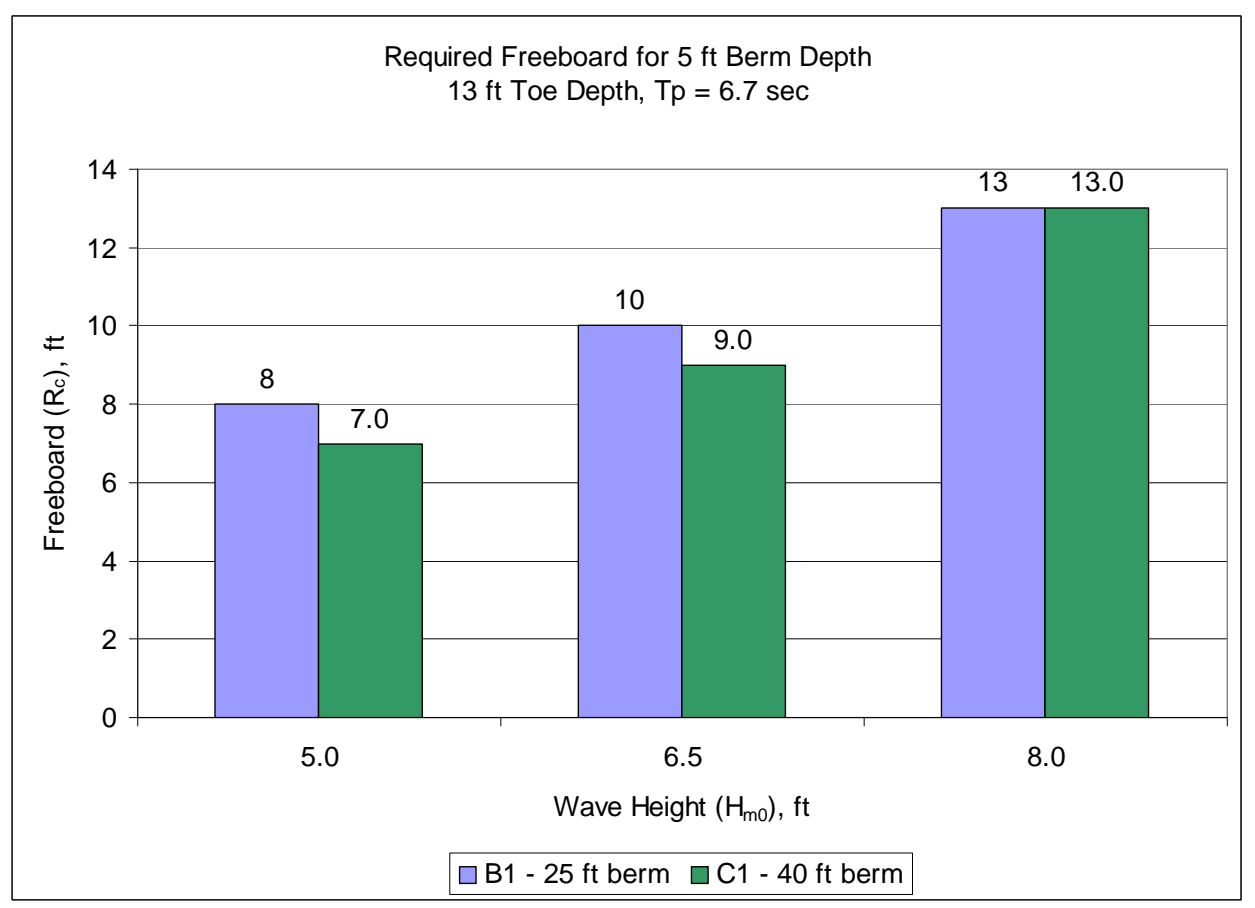

Figure 12. Required freeboard for $5 \mathrm{ft}$ berm depth, varying berm widths, $13 \mathrm{ft}$ toe depth, and $T_{p}=6.7 \mathrm{sec}$. 
Tables 5 and 6 give the final width and height, respectively, of each class of structure at the freeboard required to reach the overtopping rate goal. Here structure width is measured from toe to rear edge of crest.

Table 5. Total structure width for maximum freeboard conditions with $13 \mathrm{ft}$ toe depth.

\begin{tabular}{|c|c|c|c|c|c|c|}
\hline \multirow{2}{*}{$\begin{array}{l}\text { Peak Wave } \\
\text { Period } T_{p} \text {, } \\
\text { sec }\end{array}$} & \multirow{2}{*}{$\begin{array}{l}\text { Nearshore } \\
\text { Incident } \\
\text { Wave Height } \\
H_{m o}, \mathrm{ft}\end{array}$} & \multicolumn{5}{|c|}{ Total Structure Width, ft } \\
\hline & & A1 & B1 & C1 & D1 & E1 \\
\hline \multirow[t]{3}{*}{4.8} & 5.0 & 77.0 & 93.0 & 105.0 & 99.0 & 94.5 \\
\hline & 6.5 & 86.0 & 99.0 & 111.0 & 99.0 & 94.5 \\
\hline & 8.0 & 89.0 & 105.0 & 114.0 & 108.0 & 97.5 \\
\hline \multirow[t]{3}{*}{6.7} & 5.0 & 6.0 & 99.0 & 111.0 & 99.0 & 94.5 \\
\hline & 6.5 & 89.0 & 105.0 & 117.0 & 108.0 & 100.5 \\
\hline & 8.0 & 98.0 & 114.0 & 129.0 & 114.0 & 112.5 \\
\hline
\end{tabular}

Table 6. Total structure height for maximum freeboard conditions with $13 \mathrm{ft}$ toe depth.

\begin{tabular}{|c|c|c|c|c|c|c|}
\hline \multirow{2}{*}{$\begin{array}{l}\text { Peak Wave } \\
\text { Period } T_{p} \text {, } \\
\text { sec }\end{array}$} & \multirow{2}{*}{$\begin{array}{l}\text { Nearshore } \\
\text { Incident } \\
\text { Wave Height } \\
\mathrm{H}_{m 0}, \mathrm{ft}\end{array}$} & \multicolumn{5}{|c|}{ Total Structure Height, ft } \\
\hline & & $\mathrm{A} 1$ & B1 & C1 & D1 & E1 \\
\hline \multirow[t]{3}{*}{4.8} & 5.0 & 21.0 & 19.0 & 18.0 & 21.0 & 19.5 \\
\hline & 6.5 & 24.0 & 21.0 & 20.0 & 21.0 & 19.5 \\
\hline & 8.0 & 25.0 & 23.0 & 21.0 & 24.0 & 20.5 \\
\hline \multirow[t]{3}{*}{6.7} & 5.0 & 24.0 & 21.0 & 20.0 & 21.0 & 19.5 \\
\hline & 6.5 & 25.0 & 23.0 & 22.0 & 24.0 & 21.5 \\
\hline & 8.0 & 28.0 & 26.0 & 26.0 & 26.0 & 25.5 \\
\hline
\end{tabular}

\section{Overtopping and required crest elevation for $19 \mathrm{ft}$ toe water depth}

Two base cross-sections were tested at $19 \mathrm{ft}$ toe water depth as shown in Figures 13 and 14.

Table 7 shows the freeboard, structure width, and structure height for the conditions where the target overtopping was met. It is difficult to compare these two cross-sections for berm effectiveness because the berm depth varies between the two, but Figures 15 and 16 illustrate that B2 is the most effective cross-section at reducing the overtopping rate. 


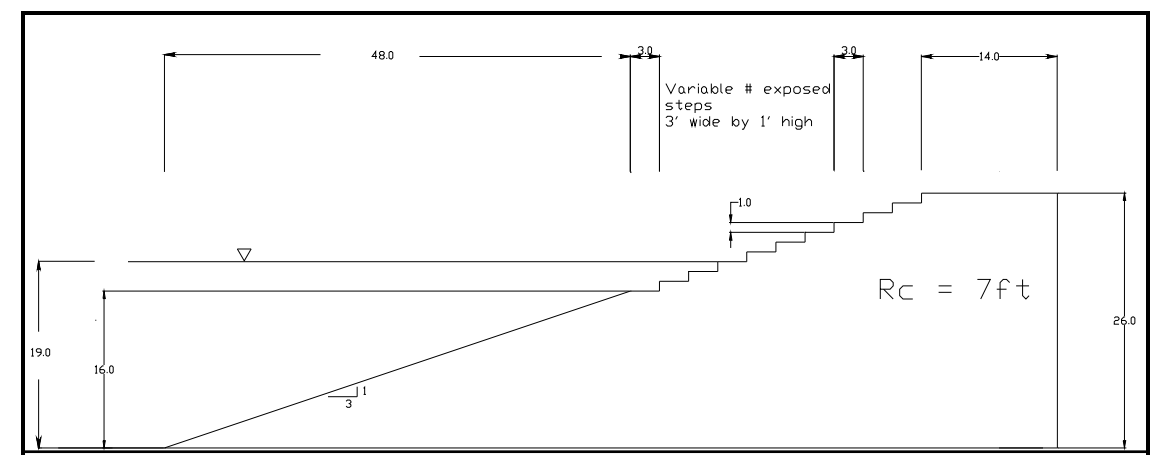

Figure 13. Base cross-section A2.

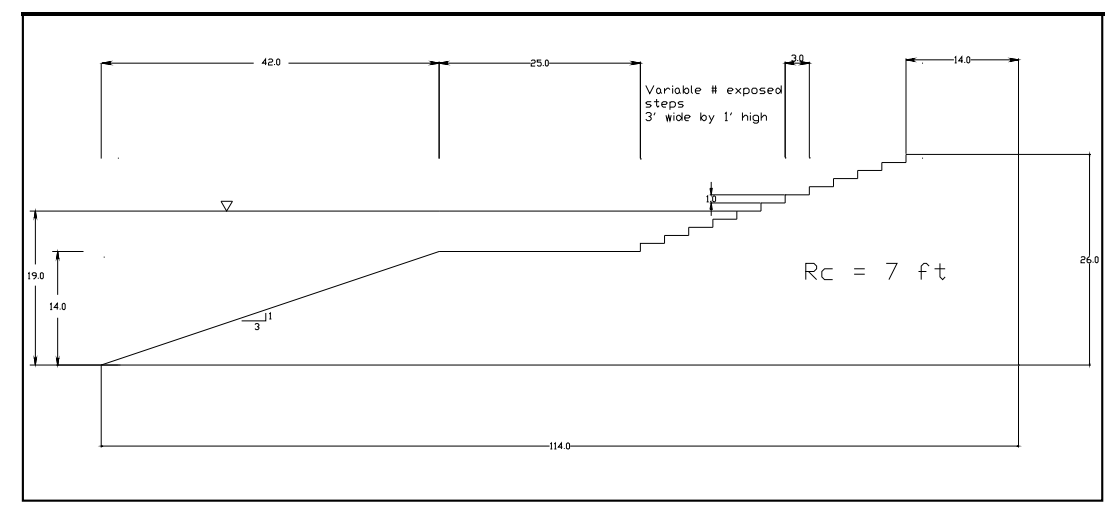

Figure 14. Base cross-section B2.

Table 7. Freeboard, width, and height for maximum freeboard conditions for $19 \mathrm{ft}$ toe water depth.

\begin{tabular}{|c|c|c|c|c|c|c|c|}
\hline \multirow{2}{*}{$\begin{array}{l}\text { Peak } \\
\text { Wave } \\
\text { Period } T_{p} \text {, } \\
\text { sec }\end{array}$} & \multirow{2}{*}{$\begin{array}{l}\text { Nearshore } \\
\text { Incident } \\
\text { Wave } \\
\text { Height } \mathrm{H}_{\mathrm{mo}} \text {, } \\
\mathrm{ft}\end{array}$} & \multicolumn{2}{|c|}{ Freeboard $R_{c}, \mathrm{ft}$} & \multicolumn{2}{|c|}{ Total Structure Width, ft } & \multicolumn{2}{|c|}{ Total Structure Height, $\mathrm{ft}$} \\
\hline & & $\mathrm{A} 2$ & B2 & A2 & B2 & A2 & B2 \\
\hline \multirow[t]{3}{*}{4.8} & 5.0 & 8.0 & 5.0 & 95 & 108 & 27 & 24 \\
\hline & 6.5 & 10.0 & 6.0 & 101 & 111 & 29 & 25 \\
\hline & 8.0 & 12.0 & 7.0 & 107 & 114 & 31 & 26 \\
\hline \multirow[t]{3}{*}{6.7} & 5.0 & 10.0 & 7.0 & 101 & 114 & 29 & 26 \\
\hline & 6.5 & 12.0 & 8.0 & 107 & 117 & 31 & 27 \\
\hline & 8.0 & 15.0 & 10.0 & 116 & 123 & 34 & 29 \\
\hline
\end{tabular}




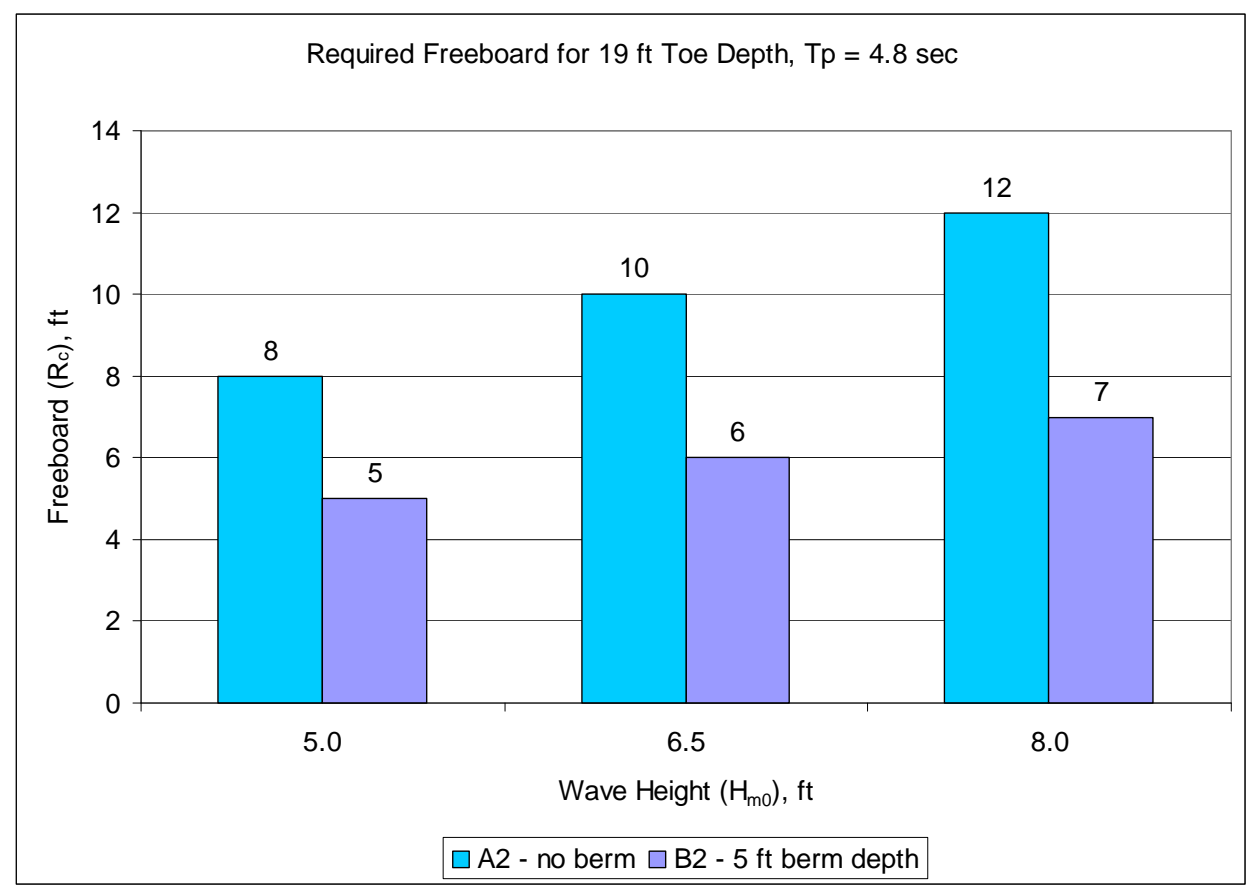

Figure 15. Required freeboard for $19 \mathrm{ft}$ toe water depth and $T_{p}=4.8 \mathrm{sec}$.

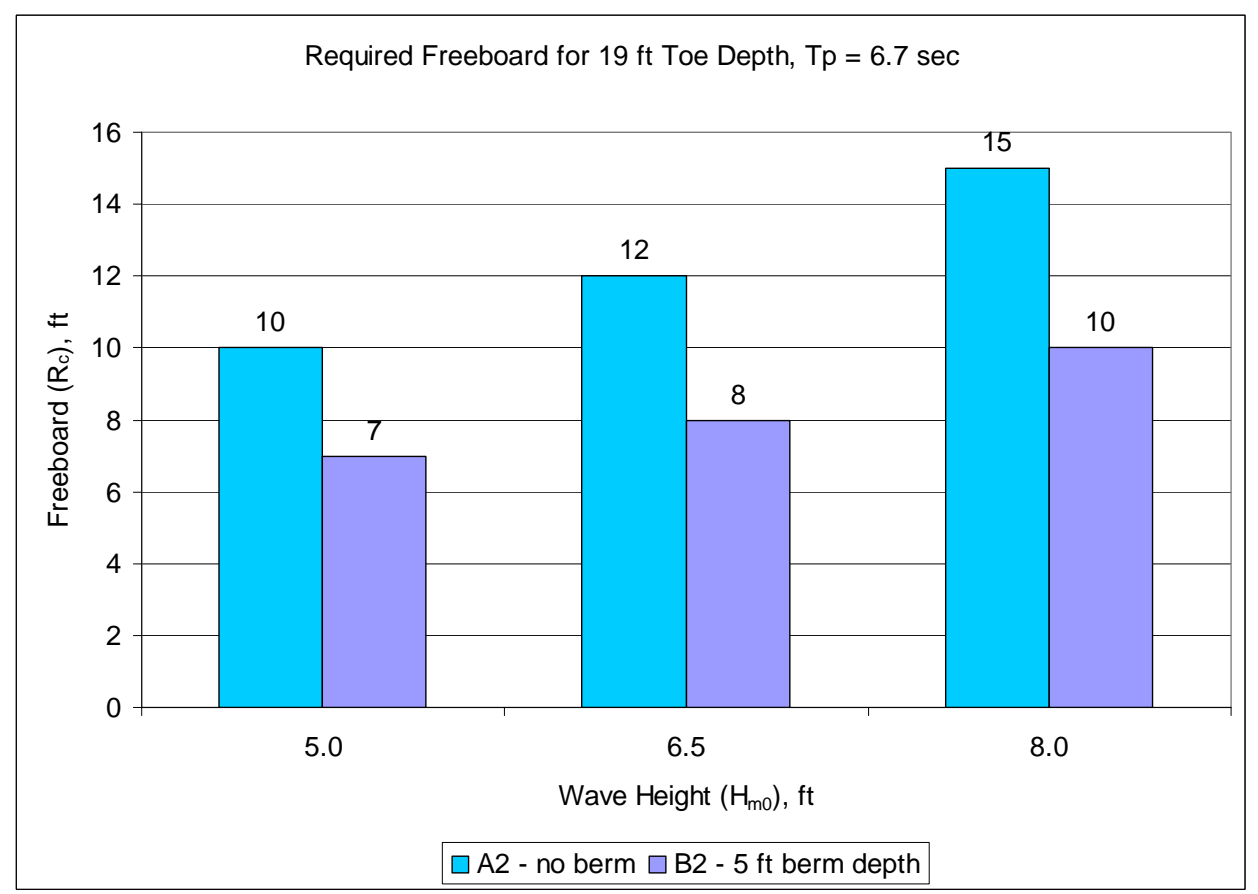

Figure 16. Required freeboard for $19 \mathrm{ft}$ toe water depth and $\mathrm{Tp}=6.7 \mathrm{sec}$. 
Overtopping and required crest elevation for $25 \mathrm{ft}$ toe water depth

Each class of cross-section was tested at the $25 \mathrm{ft}$ toe water depth.

Figures 17-21 show the base cross-section drawings for each class.

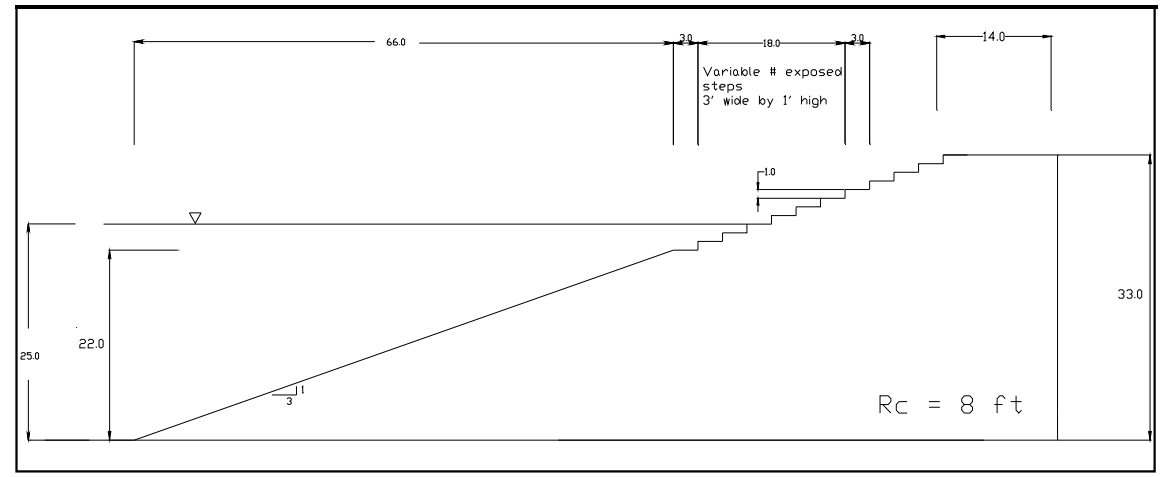

Figure 17. Base cross-section A3.

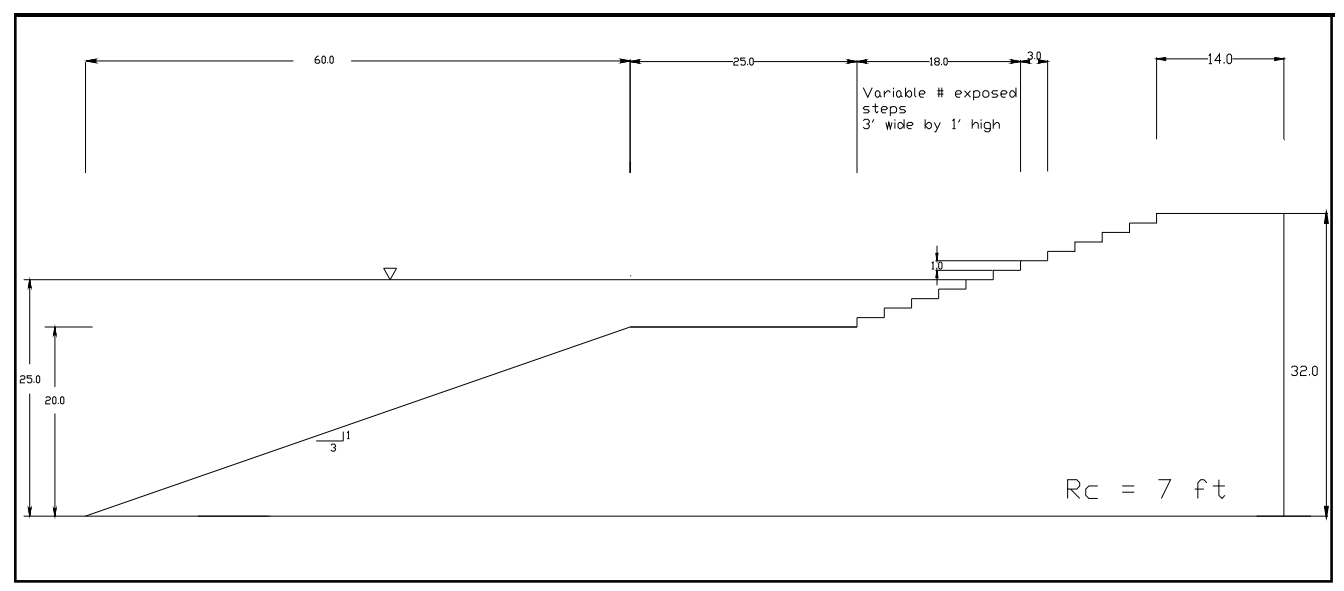

Figure 18. Base cross-section B3.

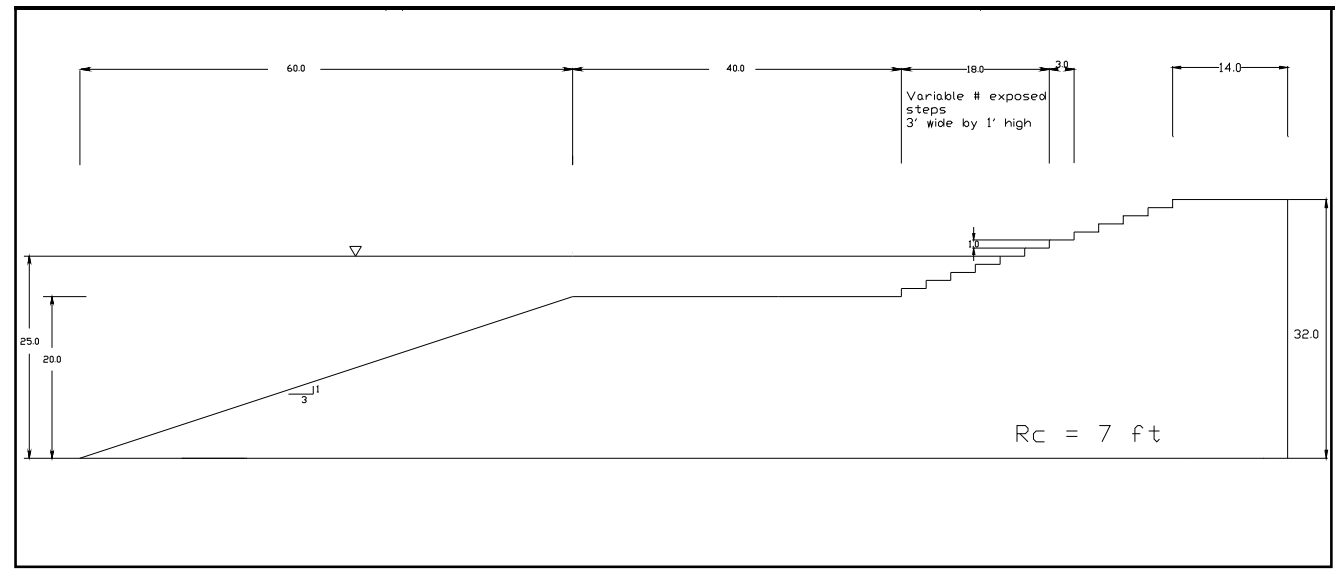

Figure 19. Base cross-section C3. 


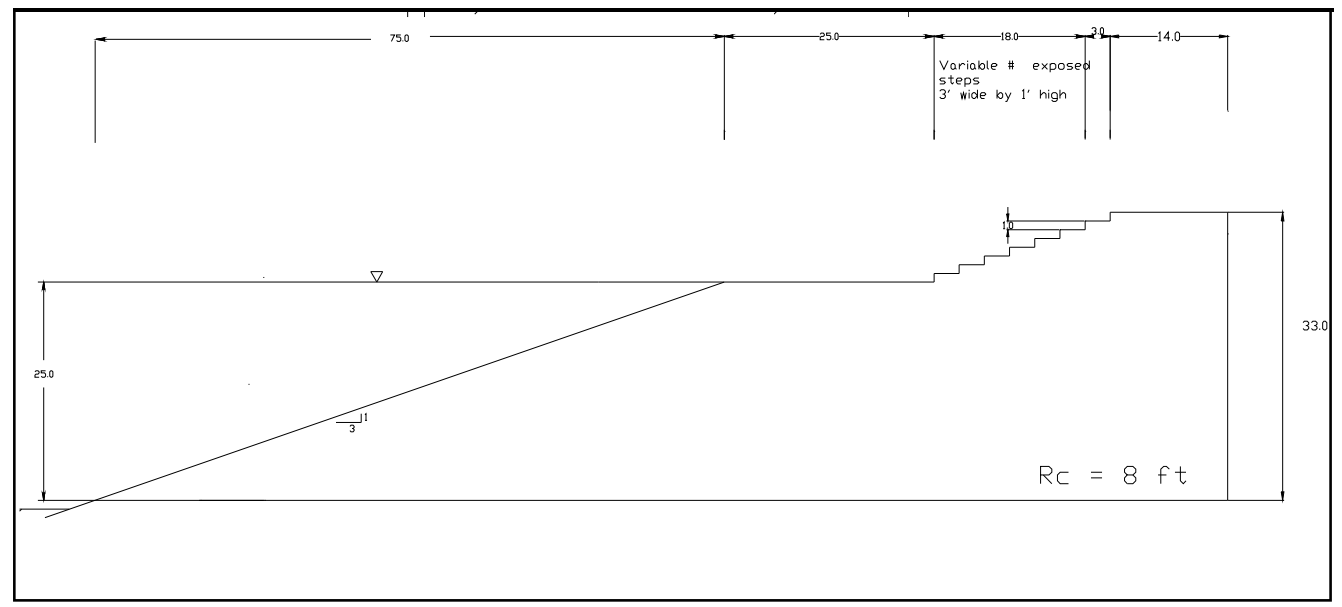

Figure 20. Base cross-section D3.

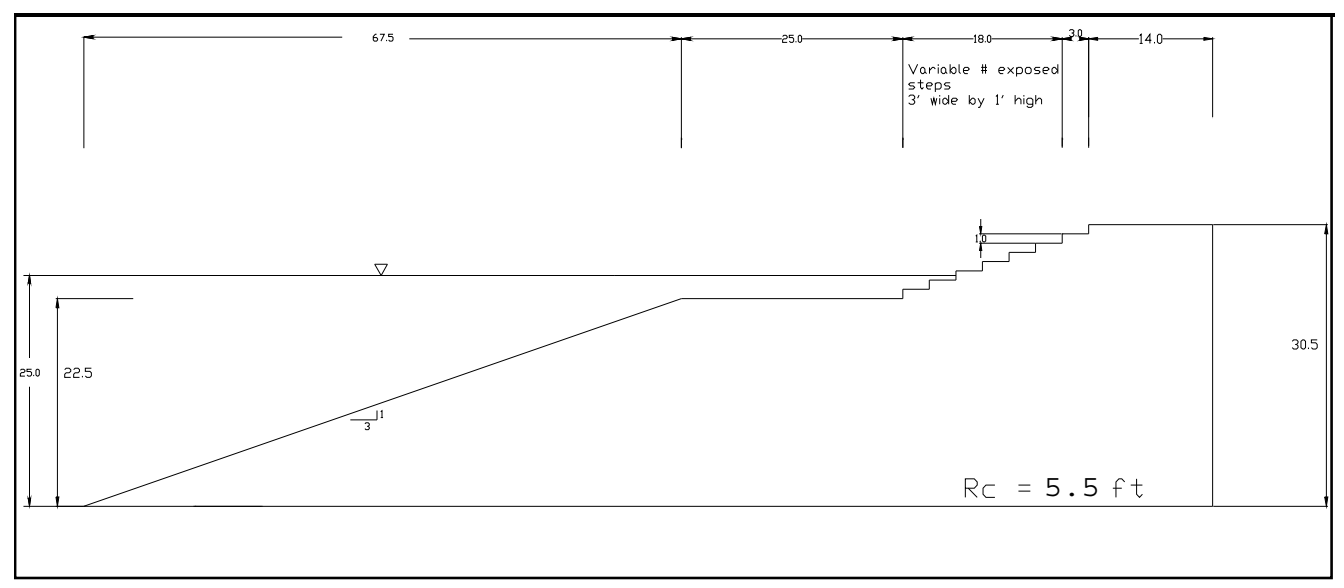

Figure 21. Base cross-section E3.

Freeboard required to achieve the target overtopping rate for toe water depth of $25 \mathrm{ft}$ is summarized in Table 8.

Table 8. Freeboard required to achieve target overtopping rate for $25 \mathrm{ft}$ toe water depth.

\begin{tabular}{|l|l|l|l|l|r|r|}
\hline \multirow{2}{*}{$\begin{array}{l}\text { Peak Wave } \\
\text { Period } T_{p}, \text { sec }\end{array}$} & $\begin{array}{l}\text { Nearshore Incident } \\
\text { Wave Height } H_{m 0}, \mathrm{ft}\end{array}$ & \multicolumn{5}{l}{ Freeboard $R_{c}, \mathrm{ft}$} \\
\cline { 3 - 7 } & & A3 & B3 & C3 & D3 & E3 \\
\hline \multirow{3}{*}{4.8} & 5.0 & 9.0 & 6.0 & 6.0 & 8.0 & 6.5 \\
\cline { 2 - 7 } & 6.5 & 11.0 & 8.0 & 7.0 & 8.0 & 8.5 \\
\cline { 2 - 7 } & 8.0 & 13.0 & 9.0 & 8.0 & 10.0 & 11.5 \\
\hline \multirow{3}{*}{6.7} & 5.0 & 10.0 & 8.0 & 7.0 & 9.0 & 7.5 \\
\cline { 2 - 7 } & 6.5 & 13.0 & 9.0 & 9.0 & 10.0 & 9.5 \\
\cline { 2 - 7 } & 8.0 & 16.0 & 11.0 & 10.0 & 12.0 & 11.5 \\
\hline
\end{tabular}


Figures 22 and 23 show the freeboard required to achieve the target overtopping rate for $25 \mathrm{ft}$ wide berm sections at varying depths. At this higher water level, cross-section B3 appears to be the most effective. The exceptions are at $T_{p}=4.8 \mathrm{sec}$ and $H_{m o}=6.5 \mathrm{ft}$ where cross-section $\mathrm{C}_{3}$ requires the same amount of freeboard as $\mathrm{B}_{3}$ and at $T_{p}=6.7 \mathrm{sec}$ where cross-section $\mathrm{E} 3$ requires $0.5 \mathrm{ft}$ less freeboard than $\mathrm{B} 3$.

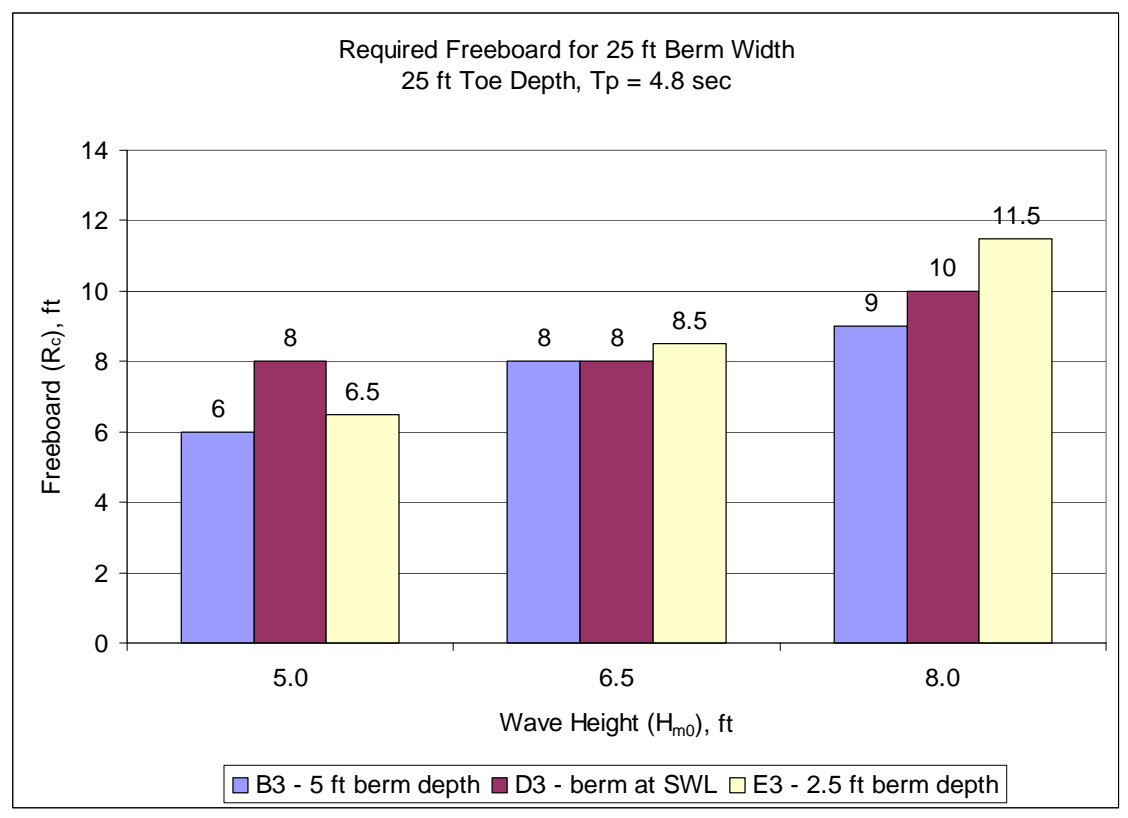

Figure 22. Required freeboard for $25 \mathrm{ft}$ berm width at varying depths, $25 \mathrm{ft}$ toe depth, and $T_{p}=4.8 \mathrm{sec}$.

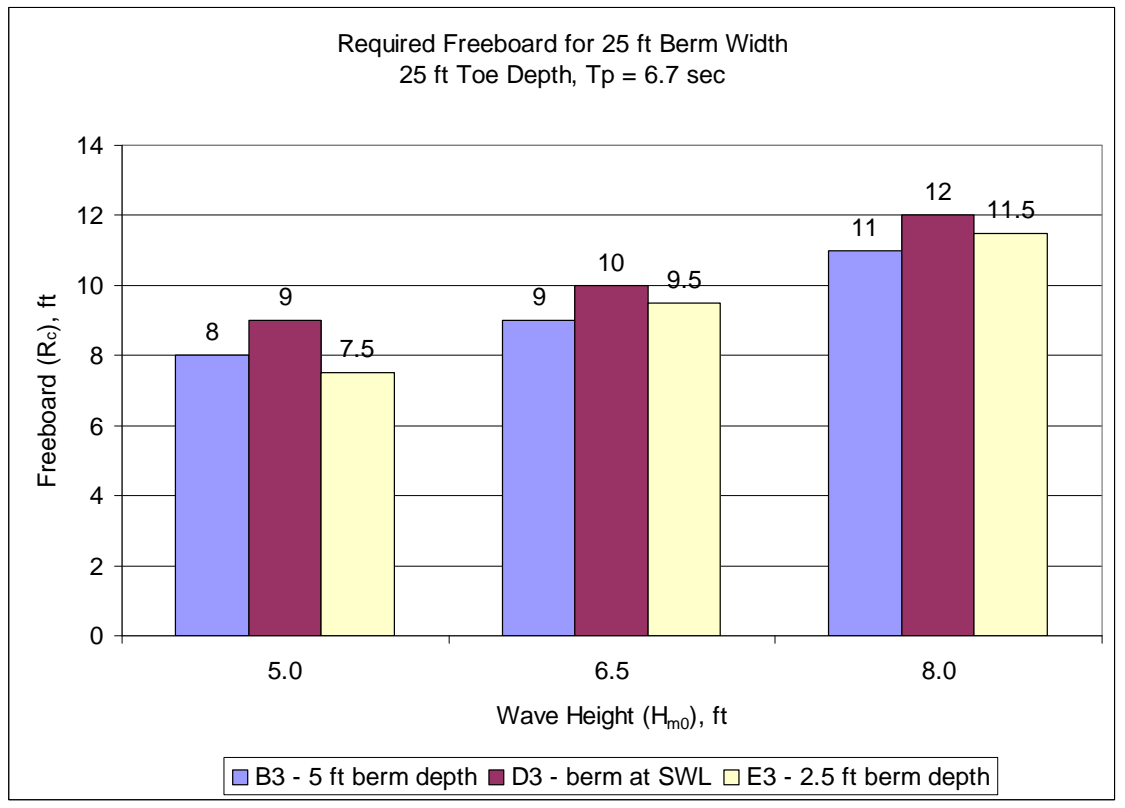

Figure 23. Required freeboard for $25 \mathrm{ft}$ berm width at varying depths, $25 \mathrm{ft}$ toe depth, and $T_{p}=6.7 \mathrm{sec}$. 
Figures 24 and 25 compare the freeboard required for cross-sections with varying berm widths when the berm is at depth $5.0 \mathrm{ft}$. The $40 \mathrm{ft}$ wide berm generally requires less freeboard than the $25 \mathrm{ft}$ wide berm. Based on the observations from this series of tests, the lowest crest elevation to reach the target overtopping would be achieved with a $40 \mathrm{ft}$ wide berm at depth $2.5 \mathrm{ft}$, which is cross-section $\mathrm{C}_{3}$. Tables 9 and 10 give the total structure widths and heights for all five structure classes at the maximum freeboard condition for the $25 \mathrm{ft}$ toe depth.

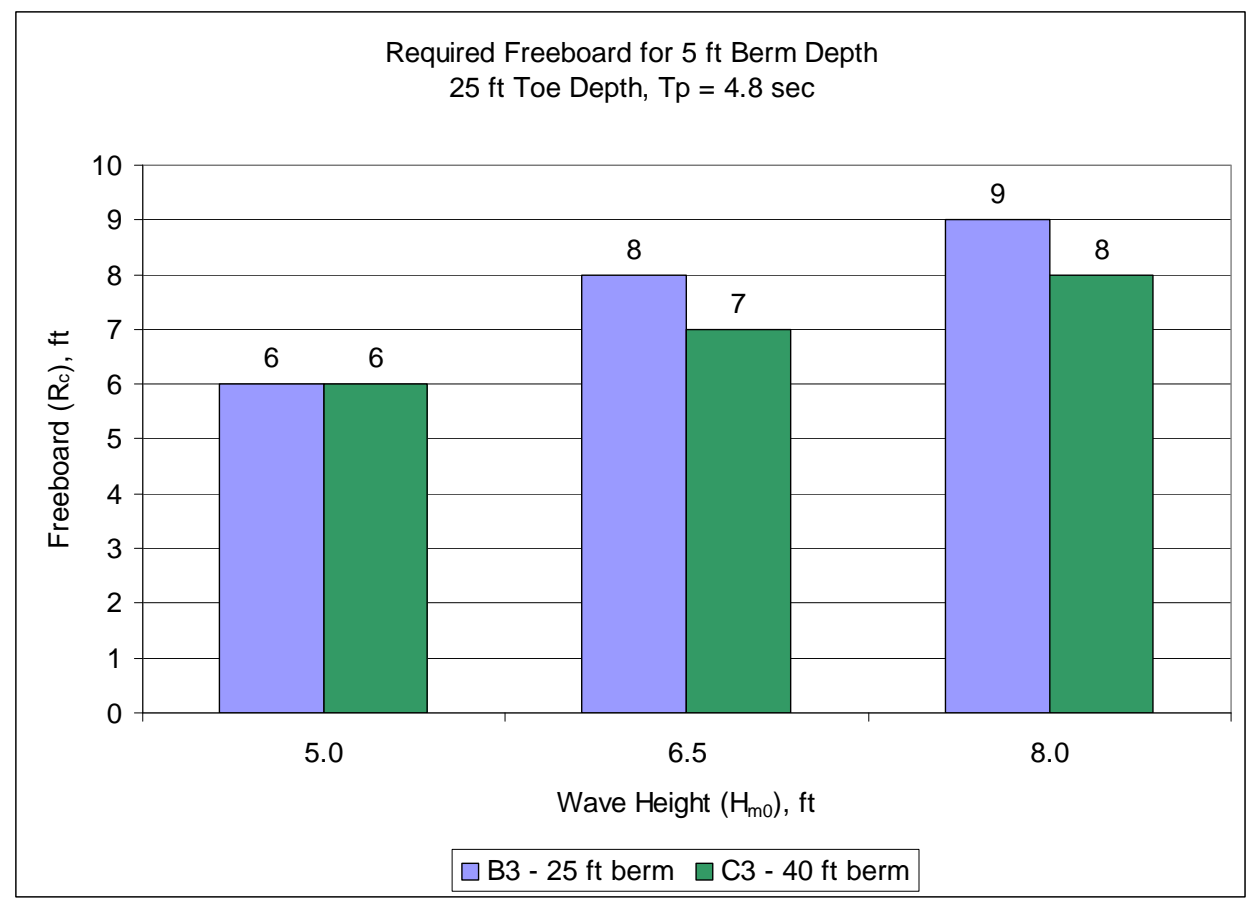

Figure 24. Required freeboard for $5 \mathrm{ft}$ berm depth with varying berm widths, $25 \mathrm{ft}$ toe depth, and $T_{p}=4.8 \mathrm{sec}$. 


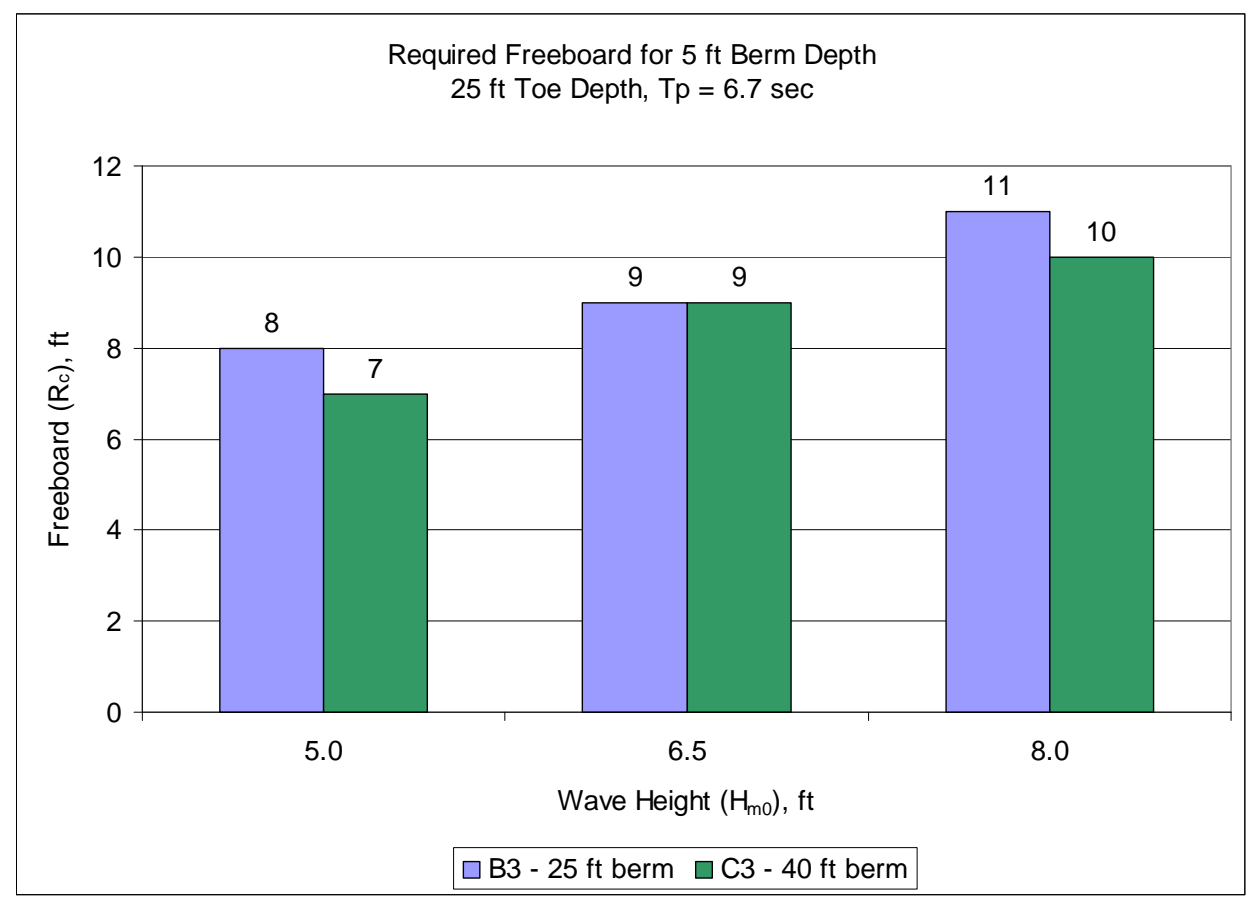

Figure 25. Required freeboard for $5 \mathrm{ft}$ berm depth with varying berm widths, $25 \mathrm{ft}$ toe depth, and $T_{p}=6.7 \mathrm{sec}$.

Table 9. Total structure width for maximum freeboard conditions and $25 \mathrm{ft}$ toe depth.

\begin{tabular}{|c|c|c|c|c|c|c|}
\hline \multirow{2}{*}{$\begin{array}{l}\text { Peak Wave } \\
\text { Period } T_{p} \text {, sec }\end{array}$} & \multirow{2}{*}{$\begin{array}{l}\text { Nearshore Incident } \\
\text { Wave Height } H_{m 0}, \mathrm{ft}\end{array}$} & \multicolumn{5}{|c|}{ Total Structure Width, ft } \\
\hline & & A3 & B3 & $\mathrm{C3}$ & D3 & E3 \\
\hline \multirow[t]{3}{*}{4.8} & 5.0 & 116 & 129 & 144 & 135 & 131 \\
\hline & 6.5 & 122 & 135 & 147 & 135 & 137 \\
\hline & 8.0 & 128 & 138 & 150 & 141 & 146 \\
\hline \multirow[t]{3}{*}{6.7} & 5.0 & 119 & 135 & 147 & 138 & 134 \\
\hline & 6.5 & 128 & 138 & 153 & 141 & 140 \\
\hline & 8.0 & 137 & 144 & 156 & 147 & 146 \\
\hline
\end{tabular}

Table 10. Total structure height for maximum freeboard conditions and $25 \mathrm{ft}$ toe depth.

\begin{tabular}{|c|c|c|c|c|c|c|}
\hline \multirow{2}{*}{$\begin{array}{l}\text { Peak Wave } \\
\text { Period } T_{p}, \text { sec }\end{array}$} & \multirow{2}{*}{$\begin{array}{l}\text { Nearshore Incident } \\
\text { Wave Height } H_{m o}, \mathrm{ft}\end{array}$} & \multicolumn{5}{|c|}{ Total Structure Height, ft } \\
\hline & & A3 & B3 & $\mathrm{C3}$ & D3 & E3 \\
\hline \multirow[t]{3}{*}{4.8} & 5.0 & 34 & 31 & 31 & 33 & 32 \\
\hline & 6.5 & 36 & 33 & 32 & 33 & 34 \\
\hline & 8.0 & 38 & 34 & 33 & 35 & 37 \\
\hline \multirow[t]{3}{*}{6.7} & 5.0 & 35 & 33 & 32 & 34 & 33 \\
\hline & 6.5 & 38 & 34 & 34 & 35 & 35 \\
\hline & 8.0 & 41 & 36 & 35 & 37 & 37 \\
\hline
\end{tabular}




\section{Overtopping prediction}

A large number of empirical equations have been published concerning wave overtopping discharge (e.g., CEM 2002, EurOtop 2007). Despite the variation in form, most equations yield similar results, within an order of magnitude. It should be noted that the equations from the CEM and EurOtop manuals were all fit to the data in this study. The comparisons suggested that the equations all have roughly the same trends but the agreement between the equations is poor. In this report, we start with the most recent design guidance as presented in the EurOtop Manual. The general equations for overtopping discharge are given as

$$
Q=0.067 \cdot \exp (-4.75 \cdot R)
$$

where

$$
\begin{aligned}
Q=\frac{q}{\sqrt{g \cdot H_{m 0}^{3}}} \cdot \frac{\sqrt{\tan \alpha}}{\gamma_{b} \xi_{0}}, \quad R=\frac{R_{c}}{H_{m 0}} \cdot \frac{1}{\xi_{o} \gamma_{b} \cdot \gamma_{r}} & \xi_{0}<2 \\
\frac{q}{\sqrt{g \cdot H_{m 0}^{3}}} \leq 0.2 \cdot \exp \left(-2.6 \frac{R_{c}}{H_{m 0}} \cdot \frac{1}{\gamma_{r}}\right) & \xi_{0}>2
\end{aligned}
$$

with application probably in the range based on CEM (Table VI-5-11)

$$
0.3<\frac{R_{c}}{H_{m 0}} \cdot \frac{\sqrt{s_{o}}}{\tan \alpha} \cdot \frac{1}{\gamma_{b} \cdot \gamma_{r}}<2
$$

and

$$
\begin{aligned}
q & =\text { overtopping rate per unit length of structure } \\
g & =\text { acceleration due to gravity } \\
\gamma_{b} & =\text { berm correction or reduction factor } \\
\gamma_{\mathrm{r}} & =\text { roughness correction or reduction factor } \\
S_{0} & =H_{m o} / L_{m-1, o}=\text { wave steepness } \\
L_{m-1,0} & =g T_{m-1,0}^{2} / 2 \pi=\text { deep water wave length } \\
T_{m-1,0} & =m_{-1} / m_{0}=\text { negative first moment wave period } \\
m_{n} & =\int f^{n} S(f) d f
\end{aligned}
$$




$$
\begin{aligned}
\alpha & =\text { structure slope angle } \\
\xi_{o} & =\tan \alpha / \sqrt{s_{o}}
\end{aligned}
$$

The coefficient -4.75 in Equation 1 can be considered normally distributed with standard deviation 0.5 for reliability calculations. Similarly, the coefficient -2.6 in Equation 3 can be considered normally distributed with standard deviation 0.35 . For this study, the range of application using Equation 4 is $0.45-2.2$.

Equations 1-3 and data for the no-berm sections A1, A2, and A3 are plotted in Figure 26. The roughness coefficient was set to $\gamma_{r}=0.60$ in order to achieve a good fit. Figure 26 also shows that the data exhibit a curvature that is concave downward indicating that the form of Equations 1-3 is not quite correct. However, there are not sufficient data to justify changing the empirical equations. Use of the $T_{m-1, \mathrm{o}}$ wave period parameter is fairly new. It is recommended over $T_{p}$ because $T_{p}$ can be fairly uncertain depending on the smoothness of the wave spectrum. $T_{m-1,0}$, like $H_{m 0}$, tends to be a more stable parameter because it is an integral property of the wave spectrum. The downside of using $T_{m-1,0}$ is that it is not usually available from hindcasts or measurements. The EurOtop manual recommends to use $T_{p} / T_{m-1, \mathrm{o}}=1.1$ if $T_{m-1, \mathrm{o}}$ is not available. $T_{p} / T_{m-1, \mathrm{o}}$ ranged from 0.83 to 1.14 for this study, so the guidance in the EurOtop manual to use $T_{m-1, \mathrm{o}}=T_{p} / 1.1$ may not be conservative in all cases.

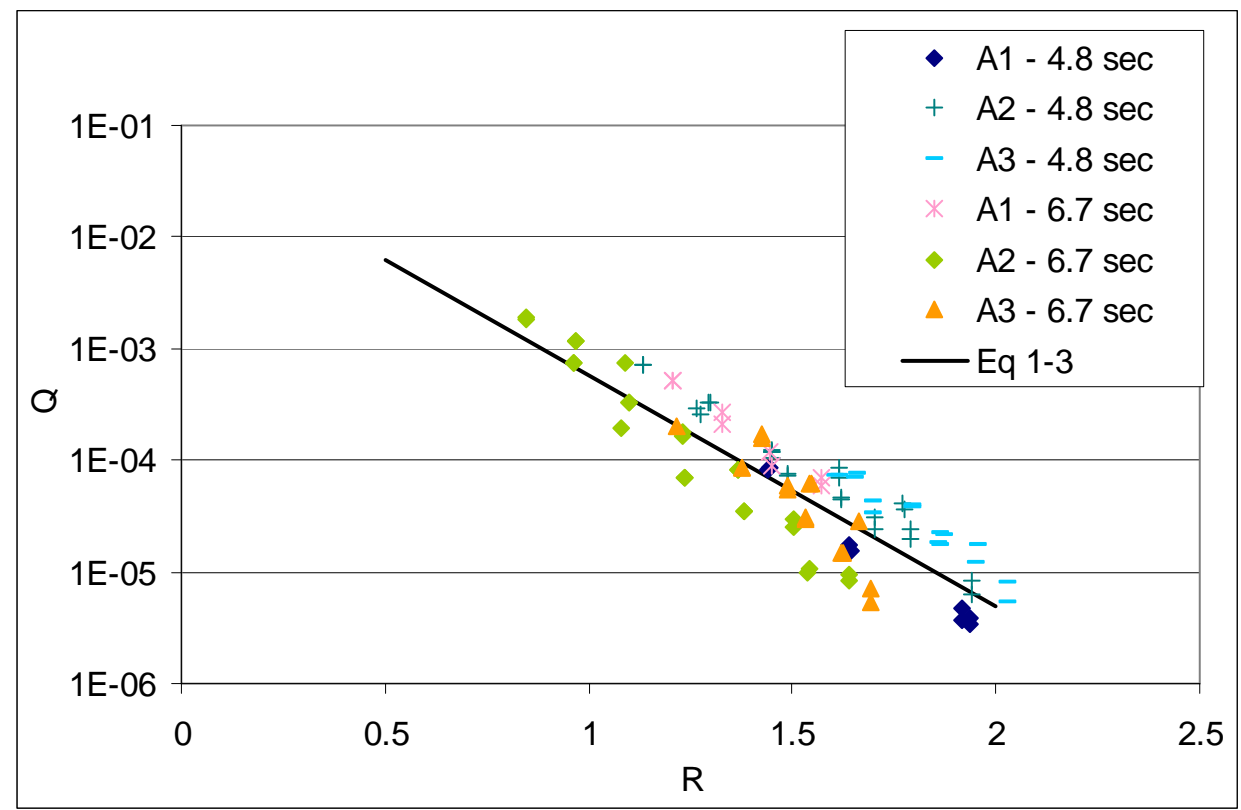

Figure 26. Data and Equations 1-3 for no-berm sections A1, A2 and A3. 
Berms are effective at reducing wave runup and overtopping. The CEM and EurOtop manuals provide a berm influence factor as

$$
\gamma_{b}=1-r_{B}\left(1-r_{d b}\right) \quad 0.6 \leq \gamma_{b} \leq 1.0
$$

where $r_{B}=\frac{B}{L_{\text {berm }}}, B=$ berm width, $L_{b e r m}=B+2 H_{m o} \cot \alpha=$ distance from intersection points on sloping portions of structure located one wave height above and below berm, and

$$
r_{d b}=0.5\left(1-\cos \left(\pi \frac{d_{b}}{2 H_{m 0}}\right)\right) \text { for berm below still water line }
$$

If the berm is above the still water line, EurOtop recommends replacing $2 H_{m o}$ in Equation 6 with $R_{u 2} \%$. For this study, the berm was below the still water line for all cases.

The overtopping discharge rate measurements and Equations 1-3 for all test series are shown in Figures 27 - 30. Figure 27 shows data from all tests, Figure 28 shows Sections A (no berm) and B ( $25 \mathrm{ft}$ wide berm), Figure 29 shows Section $\mathrm{C}$ with $40 \mathrm{ft}$ wide berm and Figure 30 shows Sections D $\left(d_{b} / H_{m o}=0\right)$ and E $\left(0.30 \leq d_{b} / H_{m o} \leq 0.49\right)$ with $25 \mathrm{ft}$ wide berms at shallower depths. Berm or first step depths were in the range $0.6 \leq d_{b} / H_{m 0} \leq 1.0$ for Sections A, B, and C. Figure 28 shows some scatter, particularly for section B1, but the fit is generally good. Figures 29 and 30 illustrate that Equations 1-3 significantly under predict overtopping for cases where the berm is wide and/or shallower. This suggests that the berm influence factor $\gamma_{\mathrm{b}}$ in Equation 2 for $Q$ could be improved. 


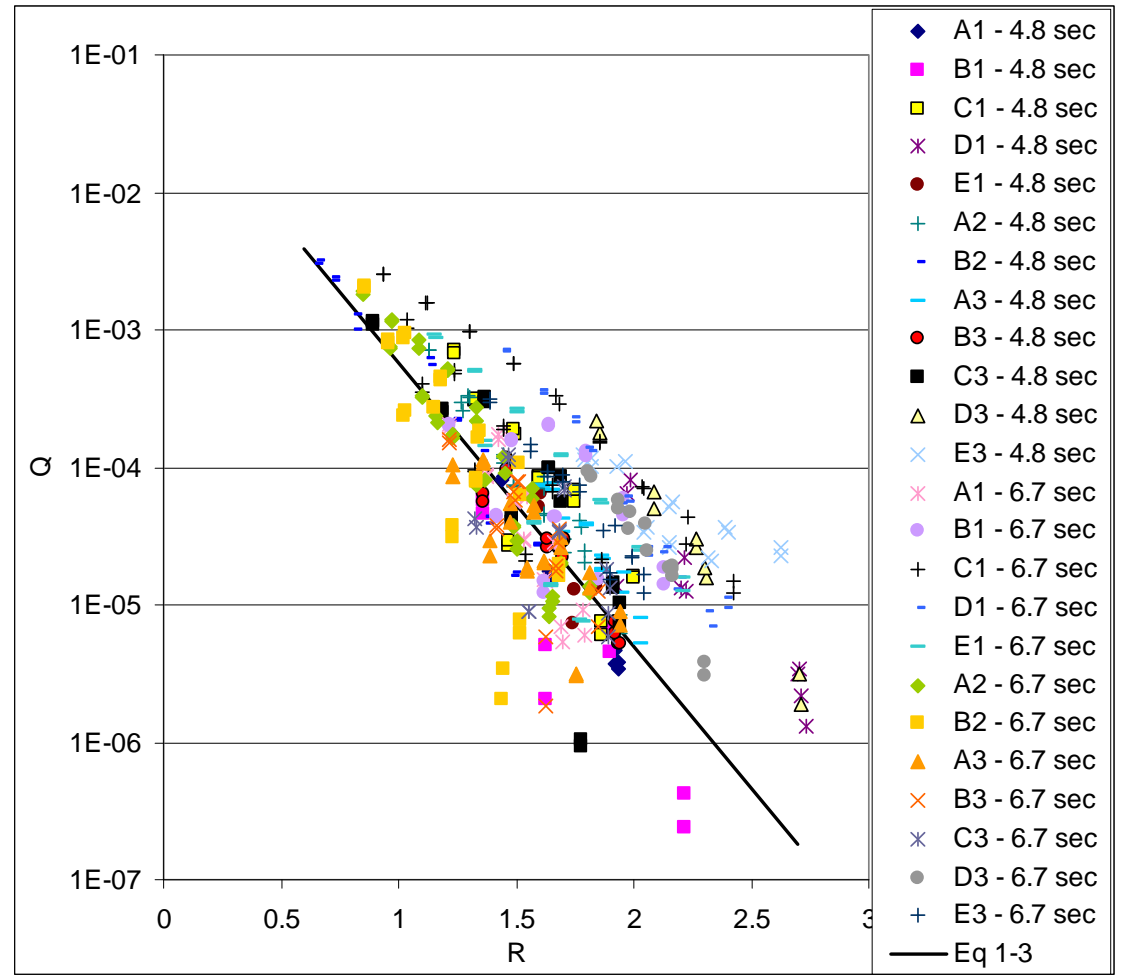

Figure 27. Normalized overtopping rate as a function of relative freeboard for all data sets.

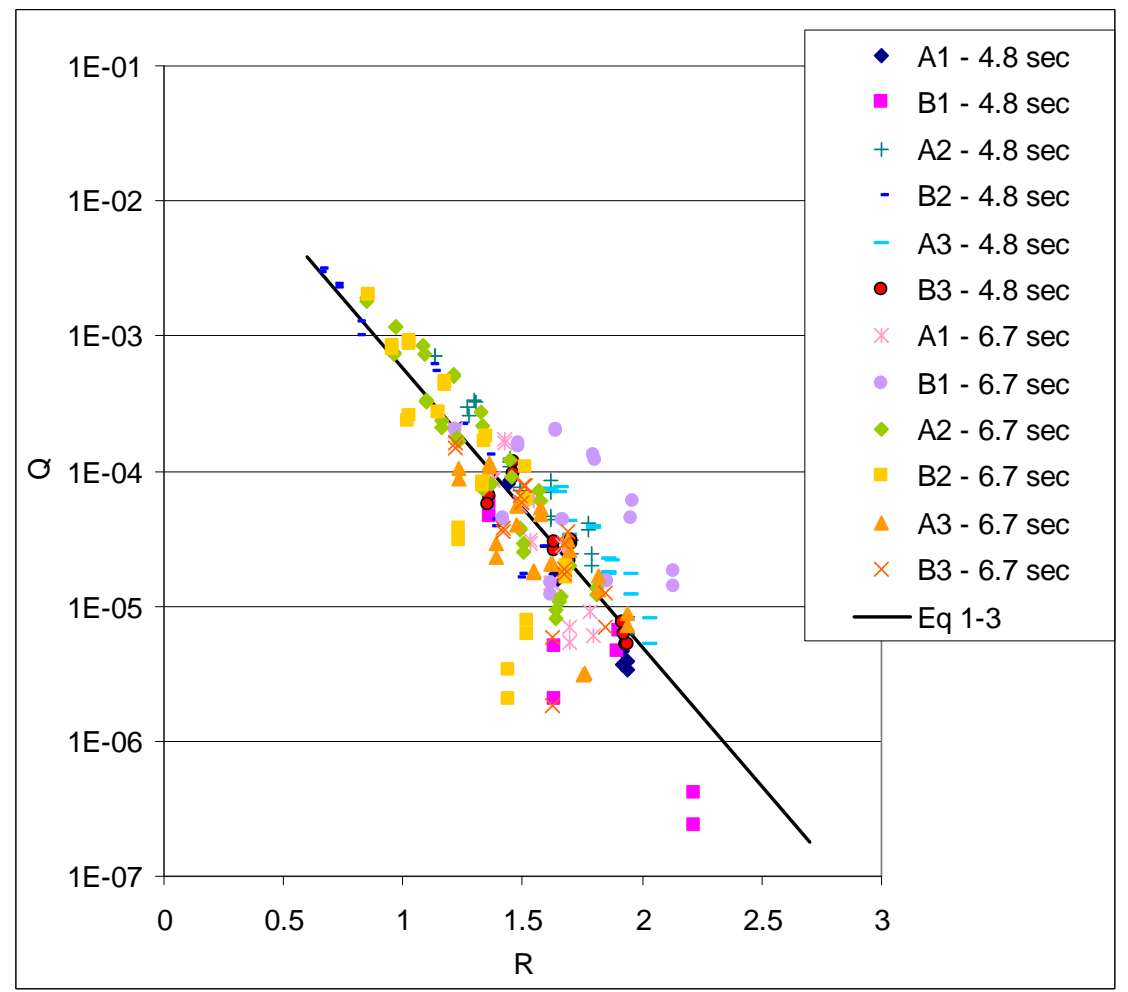

Figure 28. Normalized overtopping rate as a function of relative freeboard for Sections A (no berm) and B ( $25 \mathrm{ft}$ wide berm). 


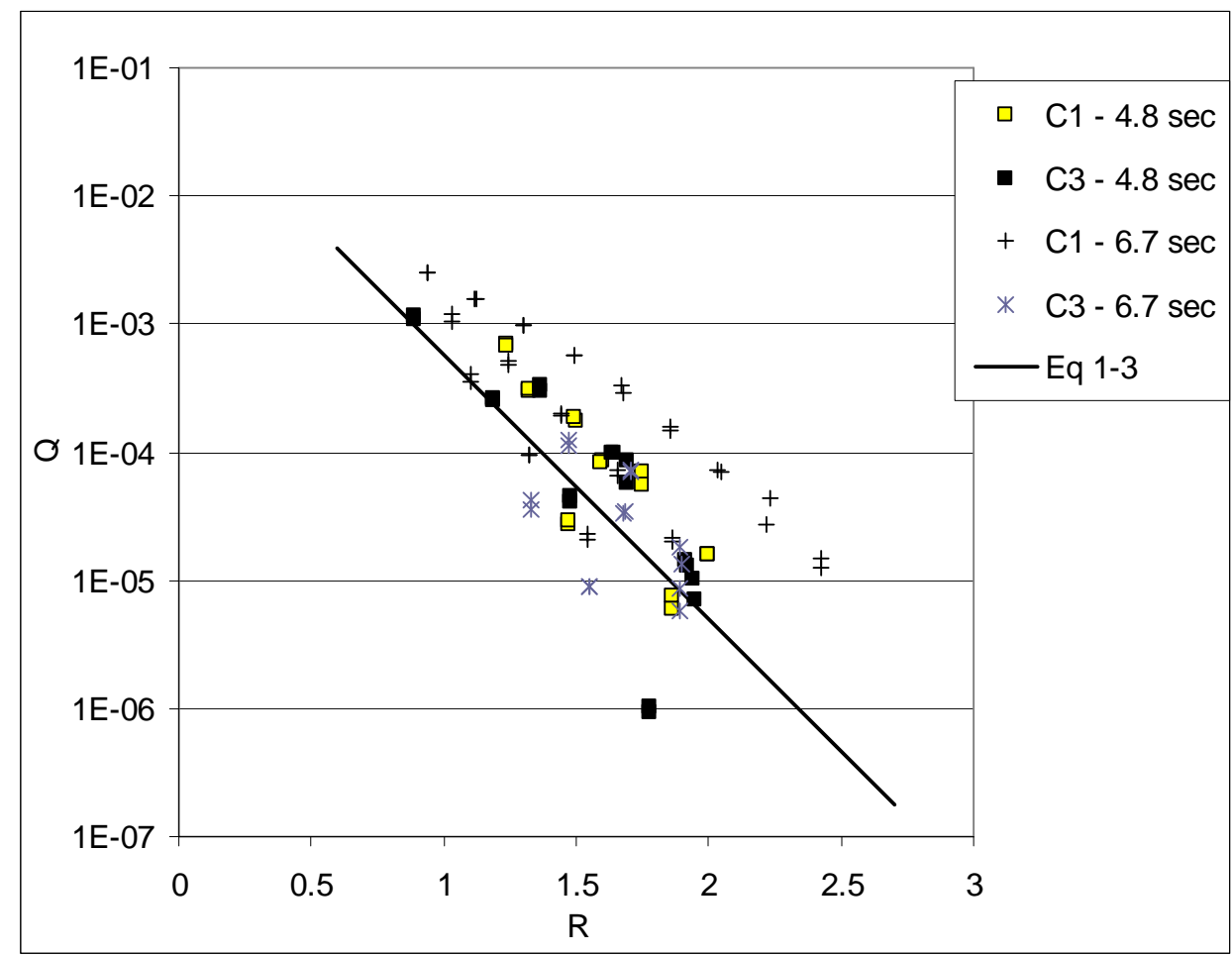

Figure 29. Normalized overtopping rate as a function of relative freeboard for Section C (40 ft wide berm).

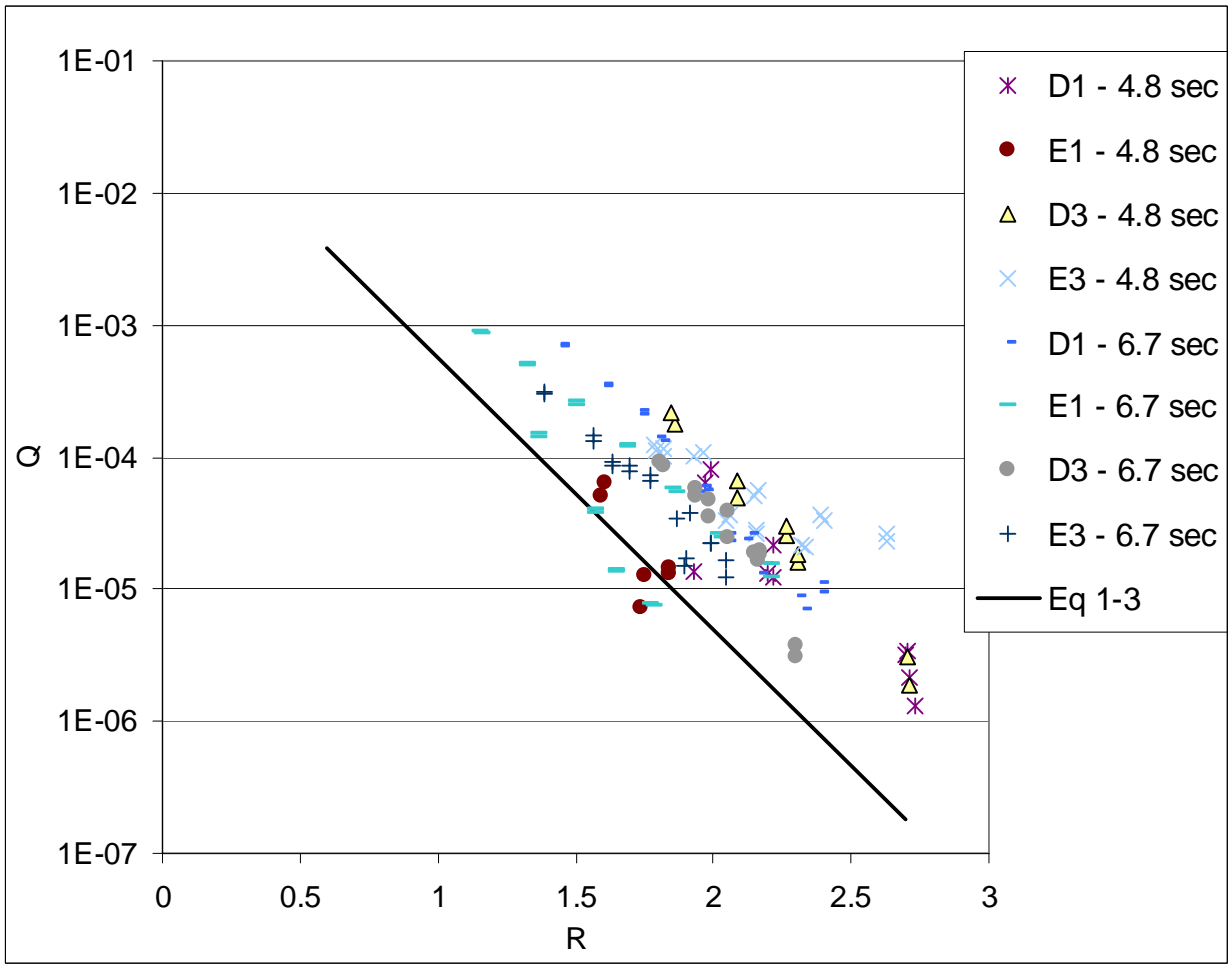

Figure 30. Normalized overtopping rate as a function of relative freeboard for Sections $D$ and $E$ ( $25 \mathrm{ft}$ wide berm). 


\section{Influence of roughness on crest height}

As discussed previously, the step roughness was influential in reducing overtopping. Figure 31 shows a comparison of Equations 1-3 computed for a smooth slope $\left(\gamma_{\mathrm{r}}=1\right)$ for comparison with Figures $27-30$ where $\gamma_{\mathrm{r}}=0.6$. Figure 32 shows an example of roughness block elements. These blocks would provide runup and overtopping reduction somewhere between the smooth slope and the stepped slope. The advantage of using segmented steps or blocks is overtopping is reduced and turtle egress from the basin is possible. The EurOtop manual suggests a block roughness coefficient of $\gamma_{\mathrm{r}}=0.75$ to 0.85 , depending on the details of the block size, block spacing, and the amount of slope coverage. Unfortunately the guidance is not very clear in any of the manuals or technical papers on the block effect. The effect of the three types of roughness is illustrated in Figure 33 where a roughness for the blocks of $\gamma_{\mathrm{r}}=0.8$ is assumed. For a short seawall at the top of the slope, the EurOtop manual suggests an additional reduction of $\gamma_{s}=0.65$ that would be multiplied by the other overtopping reduction factors.

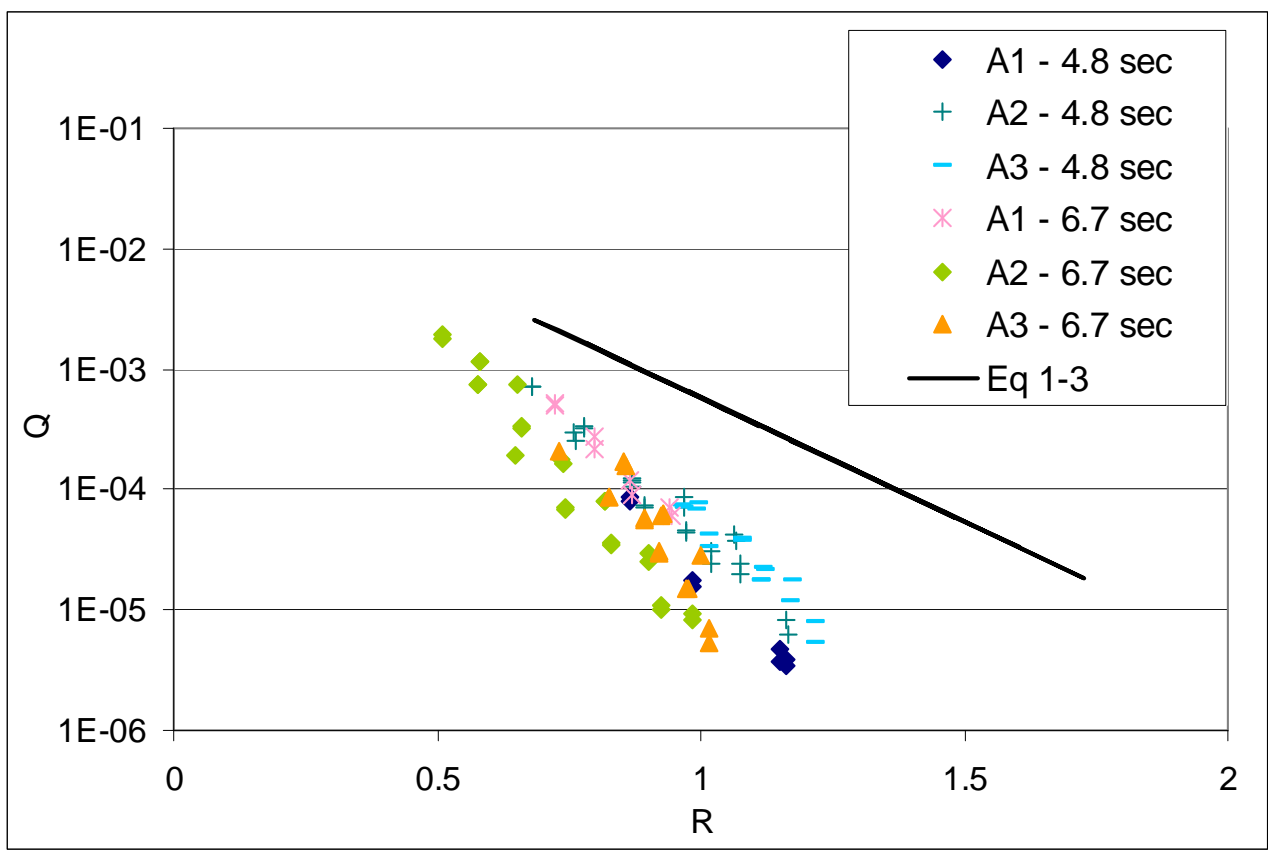

Figure 31. Normalized overtopping rate as a function of relative freeboard for Sections A1, A2, and A3 with $\gamma_{r}=1$ (smooth slope). 


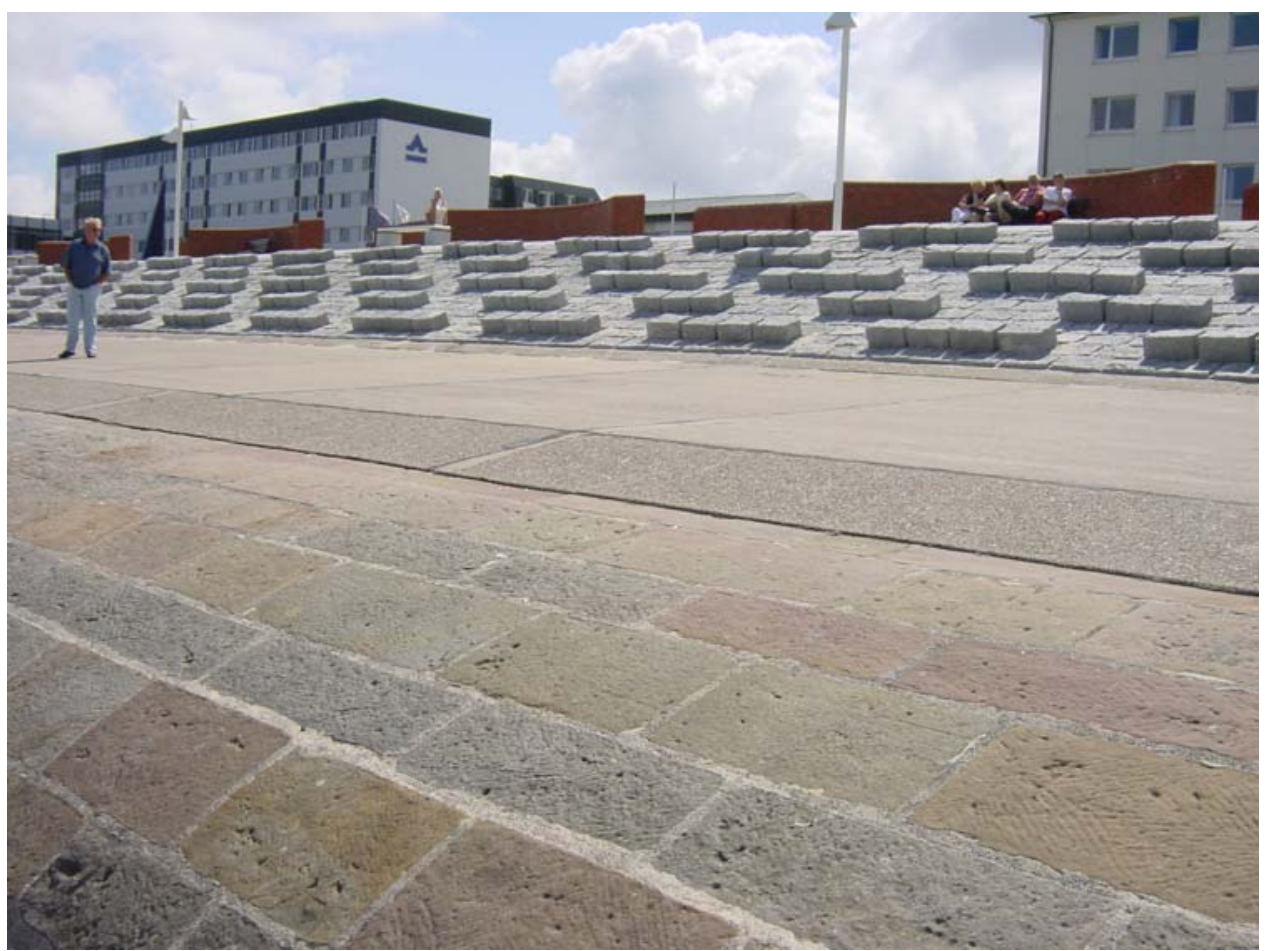

Figure 32. Illustrative photograph showing the use of discontinuous roughness elements (Photo Courtesy of Prof. Holger Schüttrumpf).

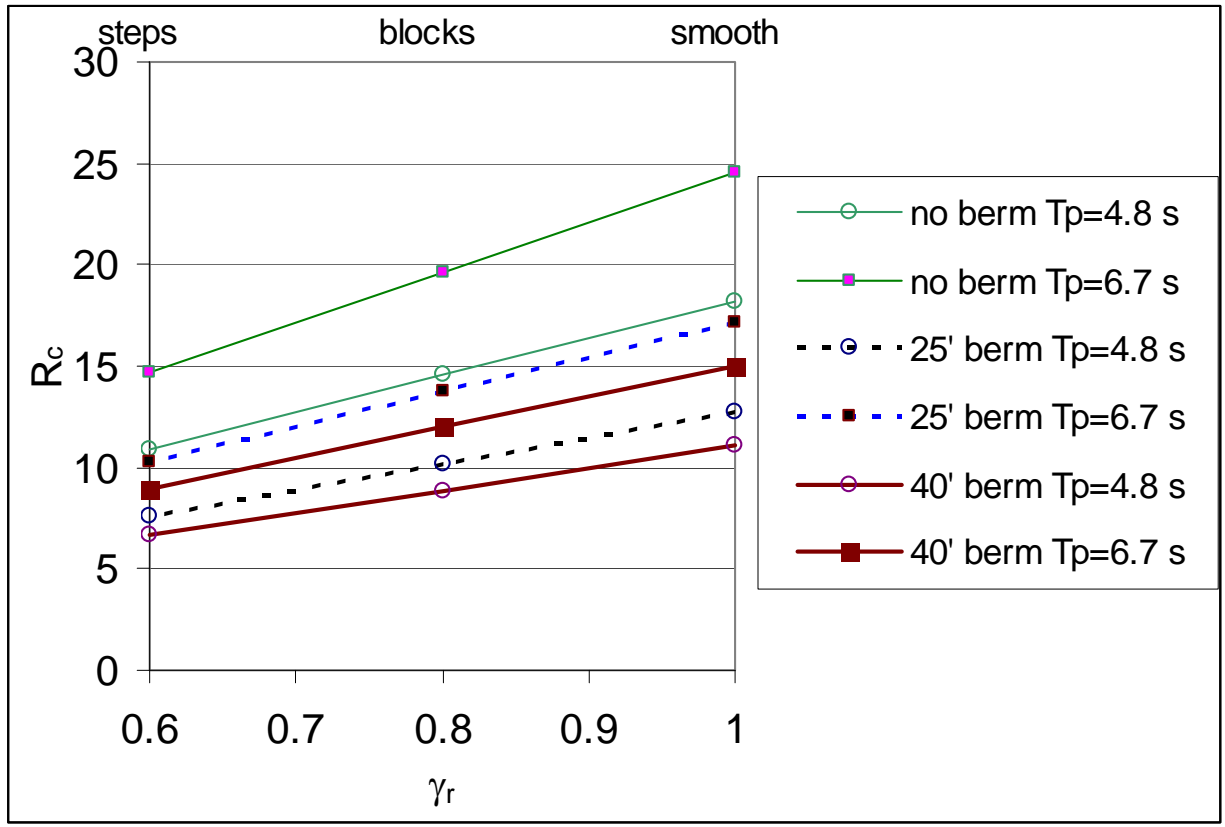

Figure 33. Maximum required freeboard as a function of roughness coefficient for $\mathrm{HmO}=8 \mathrm{ft}$. 


\section{Measured pressures}

Pressures were measured in the physical model for select cross-section, wave and water level conditions, and at select locations on the structure. Three Druck PDCR-200 pressure transducers were installed in the crosssections. Transducers were placed on the berm, on the step at the still water level, and on the crest in the center of each section. All transducers were placed in the center of the flume. The pressure transducers were mounted flush with the surface of the structure. The pressure transducers were calibrated before placing in the physical model and then the calibration was checked before each run by flooding the flume. Before each test series, the pressure transducers were zeroed when dry. Pressures were sampled at $100 \mathrm{~Hz}$. Figure 34 shows base cross-section D1 with 3 pressure transducers installed.

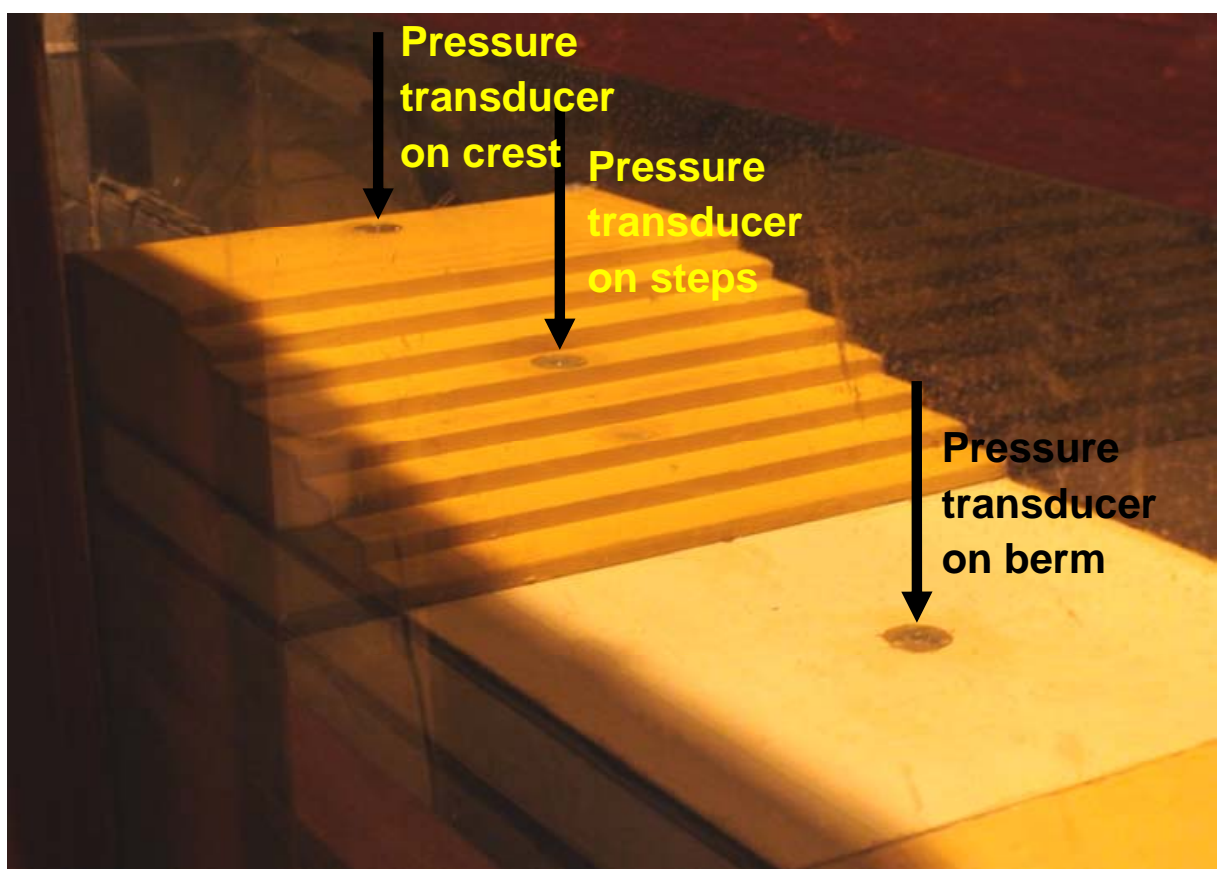

Figure 34. Base cross-section D1 with pressure transducer s installed.

Measured maximum pressure head is summarized in Table 11. Section B2 included a $25 \mathrm{ft}$ berm width, $19 \mathrm{ft}$ toe depth and $-5 \mathrm{ft}$ berm depth, crest heights $+7 \mathrm{ft}$ and $+10 \mathrm{ft}$ and instrumented step 5 at the swl. Elevations and depths are relative to swl. Section A2 included no berm, $19 \mathrm{ft}$ toe depth, $-3 \mathrm{ft}$ first instrumented step depth, crest heights $+12 \mathrm{ft}$ and $+15 \mathrm{ft}$ and middle instrumented step 3 at swl. Section D1 included a $25 \mathrm{ft}$ berm width, $13 \mathrm{ft}$ toe depth, berm at the swl, crest heights $+8 \mathrm{ft}$ and $+11 \mathrm{ft}$ and instrumented step 5 at $+5 \mathrm{ft}$. Each cross-section and wave and water level 
case was repeated 6 times with different wave realizations. The average maximum of these tests is what is listed in Table 11. The standard deviation of the maxima for the six runs ranged from 0.1 to $3.3 \mathrm{ft}$ with the greatest variation on the berm and the least variation on the crest. The berm standard deviation of the maxima was in the range $2-3 \mathrm{ft}$, the step was $1-2 \mathrm{ft}$ and the crest was $0.1-0.5 \mathrm{ft}$.

Table 11. Measured maximum pressure in feet of head.

\begin{tabular}{|c|c|c|c|c|c|c|}
\hline \multirow[b]{2}{*}{ Section } & \multirow{2}{*}{$\begin{array}{l}\text { Freeboard, } \\
R_{c} \text { in } \mathrm{ft}\end{array}$} & \multirow[b]{2}{*}{$T_{p}$, sec } & \multirow[b]{2}{*}{$H_{m 0}, \mathrm{ft}$} & \multicolumn{3}{|c|}{ Pressure Head in $\mathrm{ft}$} \\
\hline & & & & Berm & Step & Crest \\
\hline \multirow{4}{*}{ B2 } & \multirow{2}{*}{7} & 4.8 & 7.5 & 9.1 & 8.4 & 0.8 \\
\hline & & 6.7 & 8.2 & 9.4 & 10.2 & 1.6 \\
\hline & \multirow{2}{*}{10} & 4.8 & 7.5 & 7.3 & 8.5 & 0.2 \\
\hline & & 6.7 & 8.2 & 8.5 & 10.6 & 1.7 \\
\hline \multirow{4}{*}{ A2 } & \multirow{2}{*}{12} & 4.8 & 7.5 & 17.6 & 14.4 & 0.8 \\
\hline & & 6.7 & 8.4 & 19.2 & 13.7 & 1.0 \\
\hline & \multirow{2}{*}{15} & 4.8 & 7.5 & 18.6 & 12.4 & 0.4 \\
\hline & & 6.7 & 8.2 & 17.7 & 12.9 & 0.7 \\
\hline \multirow{4}{*}{ D1 } & \multirow{2}{*}{8} & 4.8 & 7.5 & 7.1 & 2.9 & 2.3 \\
\hline & & 6.7 & 8.0 & 9.2 & 6.4 & 0.5 \\
\hline & \multirow{2}{*}{11} & 4.8 & 7.5 & 7.4 & 3.6 & 1.9 \\
\hline & & 6.7 & 8.2 & 9.2 & 5.8 & 1.2 \\
\hline
\end{tabular}




\section{RANS Model}

A numerical hydrodynamic model was employed to determine maximum pressures on the structure and develop a tool for structure optimization. The parameters of interest in this task were the spatially and temporally varying wave pressure on the embankment face and the wave overtopping rates. Using a physical model to measure detailed pressure distributions for a large number of tests and structure configurations would be prohibitively expensive. The numerical model employed is referred to as Cornell Breaking Wave and Structure (COBRAS) and is discussed in detail in Lynett (2007), Lin and Liu (1998), and Hsu et al. (2002). The model is based on the two-dimensional Reynolds-Averaged Navier Stokes (RANS) equations (in the vertical plane). The model is phase- and depth-resolving and can accurately model the gross fluid dynamics and kinematics in the surf zone. This is critical for the embankment under consideration in this study because the waves break on the berm and splash up the steps. Each broken wave is drawn off the berm in the trough of the following wave and then the combined turbulent bore is swept back onto the berm and up the steps with the next wave crest. This is a highly chaotic hydrodynamic process and not well modeled using simpler phase resolving models (Boussinesq) or phase-averaged models (STWAVE).

The COBRAS model is a hybrid with direct two-way coupling between a Boussinesq model (COULWAVE) for the offshore and the RANS model nearshore. The computational requirements are less than if the model were entirely RANS. Waves are generated in the Boussinesq domain. The RANS model includes free surface tracking using the volume-of-fluid method and is coupled with a $\mathrm{k}-\varepsilon$ turbulence closure model. This model is capable of calculating the turbulent energy and energy dissipation due to wave breaking and bottom friction. The model includes sponge layers for wave absorption on either end of the model domain.

For this study, the Boussinesq and RANS spatial grids were uniform. The grid size was $\Delta x=4 \mathrm{ft}$ for the 558-ft long Boussinesq model domain and $\Delta x=0.49 \mathrm{ft}$ and $\Delta z=0.33 \mathrm{ft}$ for the $197-\mathrm{ft}$ long by 32.8 -ft high RANS model domain. Figure 35 shows the nearshore numerical model domain. 


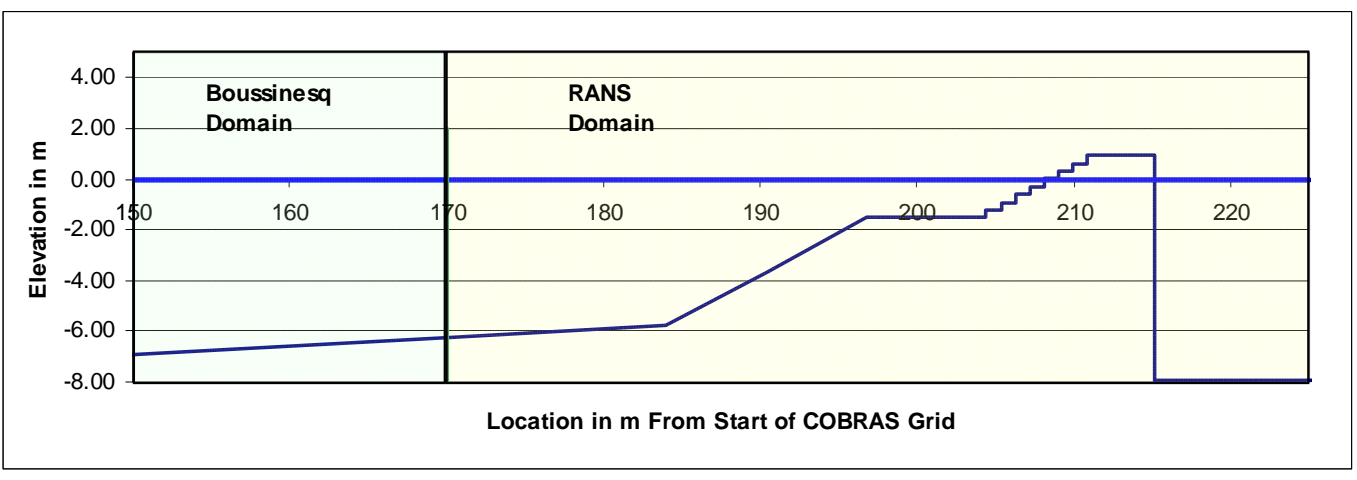

Figure 35. COBRAS model domain.

A constant time step of $0.006 \mathrm{sec}$ was used. A sensitivity series of shortduration regular wave physical and parallel numerical model tests was utilized to verify that the grid size and time step were adequate. Pressure time series were output along the structure surface. Free surface elevation time series were output at select points corresponding to wave gage locations in the physical model as well as on the structure crest.

Figure 36 shows a representative sample of the results of the wave overtopping comparison between the physical model and COBRAS. Note that the wave spectra in the COBRAS model were matched to the physical model only through the gross parameters $H_{m o}, T_{p}$, and $\gamma$. The actual synthesized wave time series were not identical. In addition, for many tests, 5 or less waves overtopped. Generally, these tests corresponded to overtopping rates of $\mathrm{o}-0.05 \mathrm{ft} 3 / \mathrm{s} / \mathrm{ft}$. The overtopping for these tests was very sensitive to the random characteristics of a wave time series realization. For example, if only a few waves overtop in a single realization, a different realization with the same gross statistical characteristics might produce no overtopping. So, significant variability between the two models, as shown in Figure 35, is expected, particularly for low overtopping cases. In this study, it was clear that the COBRAS model performed extremely well for many wave cases but not as well on others. There were indications that poor performance may have resulted from model instability when the water depth was very small on the crest. Unfortunately, there was not sufficient time to resolve the issue within the scope of the study. However, it appeared that model instability leading to poor predictions could be identified on a case by case basis so that the COBRAS model could be used for predictive purposes for this class of structure and it could provide more accurate predictions for overtopping than the empirical model for most wave and water level cases. 


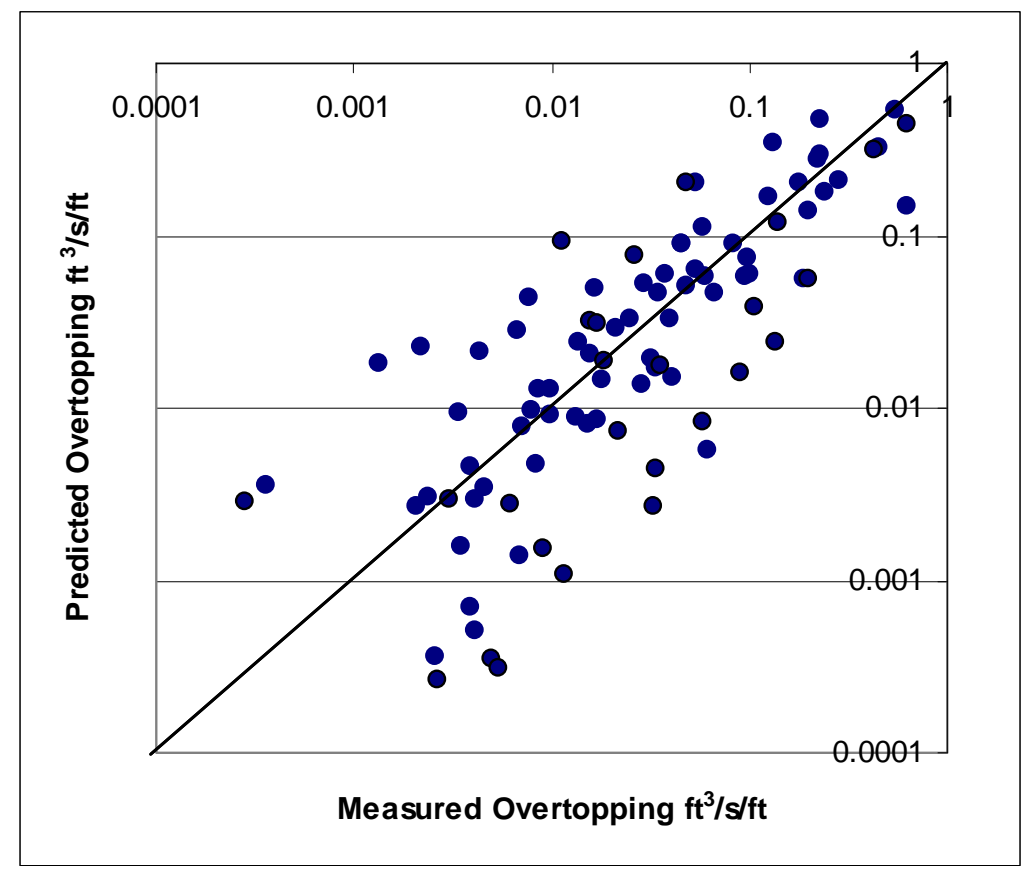

Figure 36. Wave overtopping comparison between COBRAS model and physical model measurements.

As discussed previously, COBRAS was used to determine the hydrodynamic pressures on the surface of the structure. Initially, tests were conducted using short bursts of monochromatic waves to verify simulated pressures. The COBRAS model produced accurate estimates of the pressure time series considering the complexity of the wave breaking on the berm and splashing up the steps. A weakness of the RANS model was reproduction of wave slamming pressures occurring when a collapsing air pocket was trapped between wave face and step face. The single-phase RANS model was not expected to model the physics of this process well. A two-phase model with water and compressible air would be required to capture this process. Hence, COBRAS significantly and consistently underpredicted the peak slamming pressures for these high frequency events. However, these wave slamming pressures are not significant for structure design because they occur at frequencies that are higher than the bulk of the structure response energy. The measured and RANS simulated pressures were low-pass filtered to eliminate the frequencies that exceeded the structure response frequencies. This resulted in the two time series being very close in magnitude and phase. Figure 37 shows a comparison of pressures from physical model (Lab Step 1 and 3) and RANS (COBRAS Step 1 and 3) for a short burst of monochromatic waves for section A1 with $T=6.7 \mathrm{sec}, H=\mathrm{ft}$. Here $H=$ average wave height, $T$ = wave period, $P=$ pressure, $\rho=$ fluid density, and $g=$ acceleration of gravity. The water 
surface elevation measurement on the lowest step is denoted as Wave Step 1.

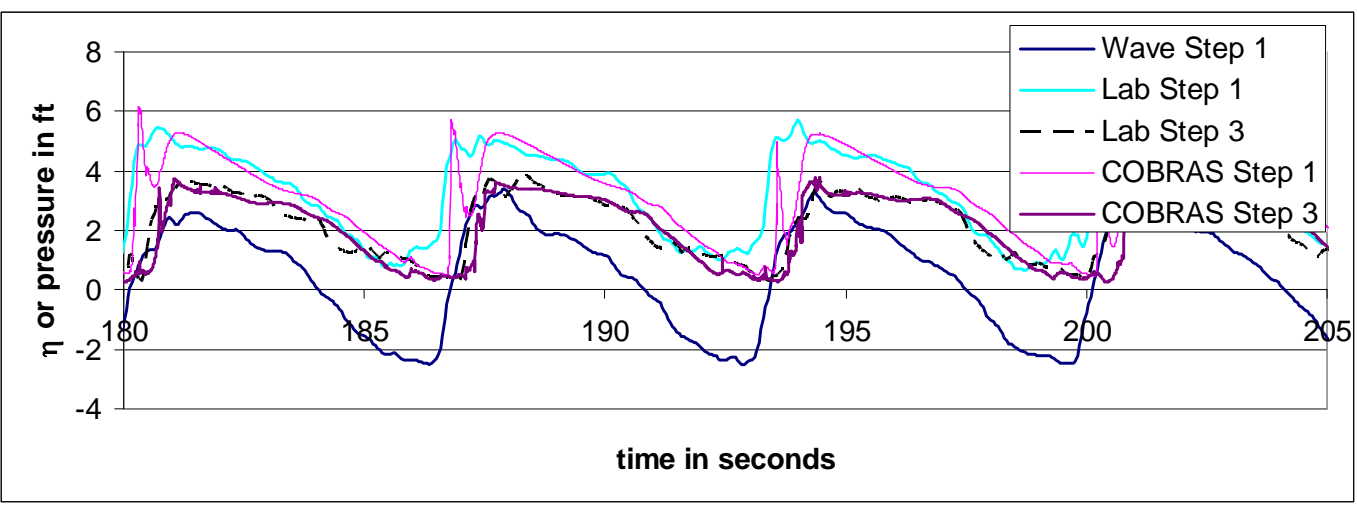

Figure 37. Pressure head time series from physical model and COBRAS for section A2.

The following results are for the same set of irregular wave test conditions summarized in the laboratory overtopping section. Figure 38 shows measured vertical profile of maximum pressure from RANS simulations for cross sections A1, B1, C1, D1, and E1. The values plotted are the maximum values for a specific test at each step elevation, with step maxima occurring at different times throughout each simulation. The specific results are from the simulations that produced absolute maximum pressures for these cross sections. These pressure profiles show mostly uniformly decreasing maximum pressure with increasing elevation.

Figures 39 - 40 summarize the maximum pressures simulated with the RANS model for all tests. These figures illustrate that maximum pressures generally increase with increasing $T_{p}$ and $H_{m o}$, as expected, although section D1 pressures decreased with increasing wave height for $T_{p}=4.8 \mathrm{sec}$. These plots show a general trend of higher pressures for less berm width, although there were many exceptions. In particular, the 40-ft berm section $\mathrm{C} 1$ produced significantly higher pressures than all other sections but only for $T_{p}=4.8 \mathrm{sec}$. Also, the $25 \mathrm{ft}$ berm often produced maximum pressures nearly the same as the no berm sections or slightly higher. Another trend that is clear is that the pressure increased with berm depth. The differences in maximum pressure head were sometimes greater than the differences in water depth. Pool depth did not produce any general trend with maximum pressure. The maximum pressures for all runs were less than $11 \mathrm{ft}$ of head except for the A section. The no-berm had the highest pressures. The longer period runs generally showed higher maximum pressures as a result of the characteristics of wave breaking. When the pressure on any step is at a maximum for any test, the pressure 
distribution across the structure has a characteristic shape of exponentially increasing with increasing depth. However, the pressure spiked often on one or more steps, due to wave slamming from the wave breaking process.

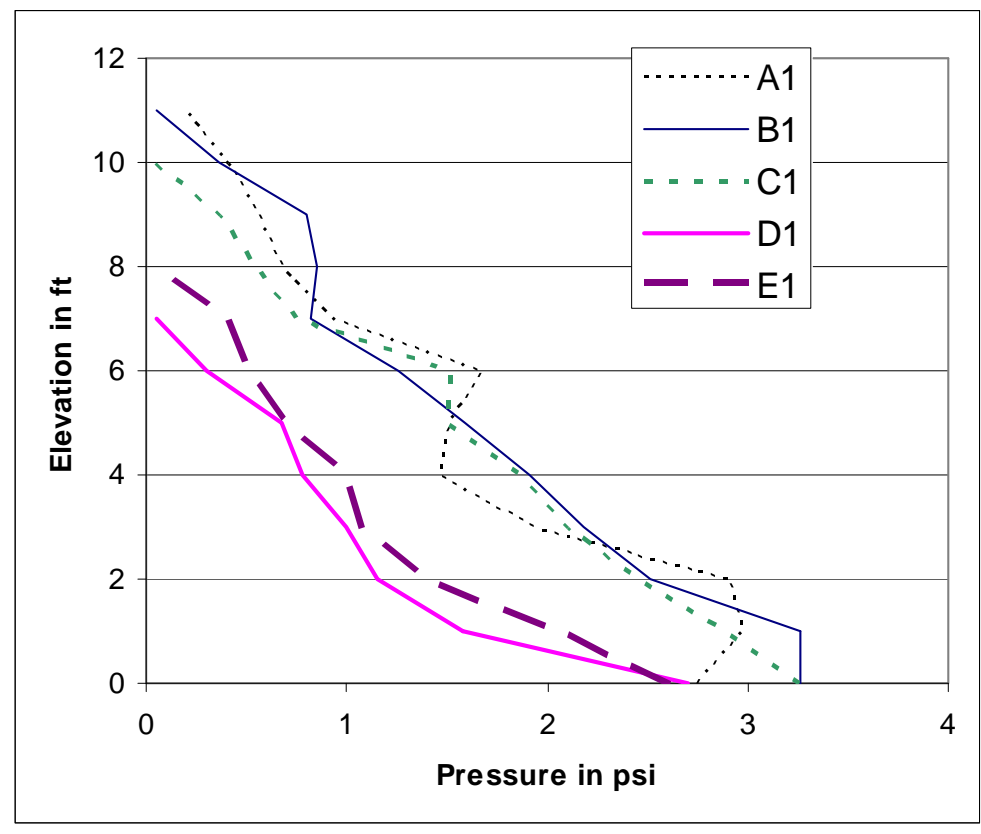

Figure 38. Pressure distributions from RANS model corresponding to maximum pressure tests for sections A1, B1, $\mathrm{C} 1, \mathrm{D} 1$, and $\mathrm{E} 1$. 


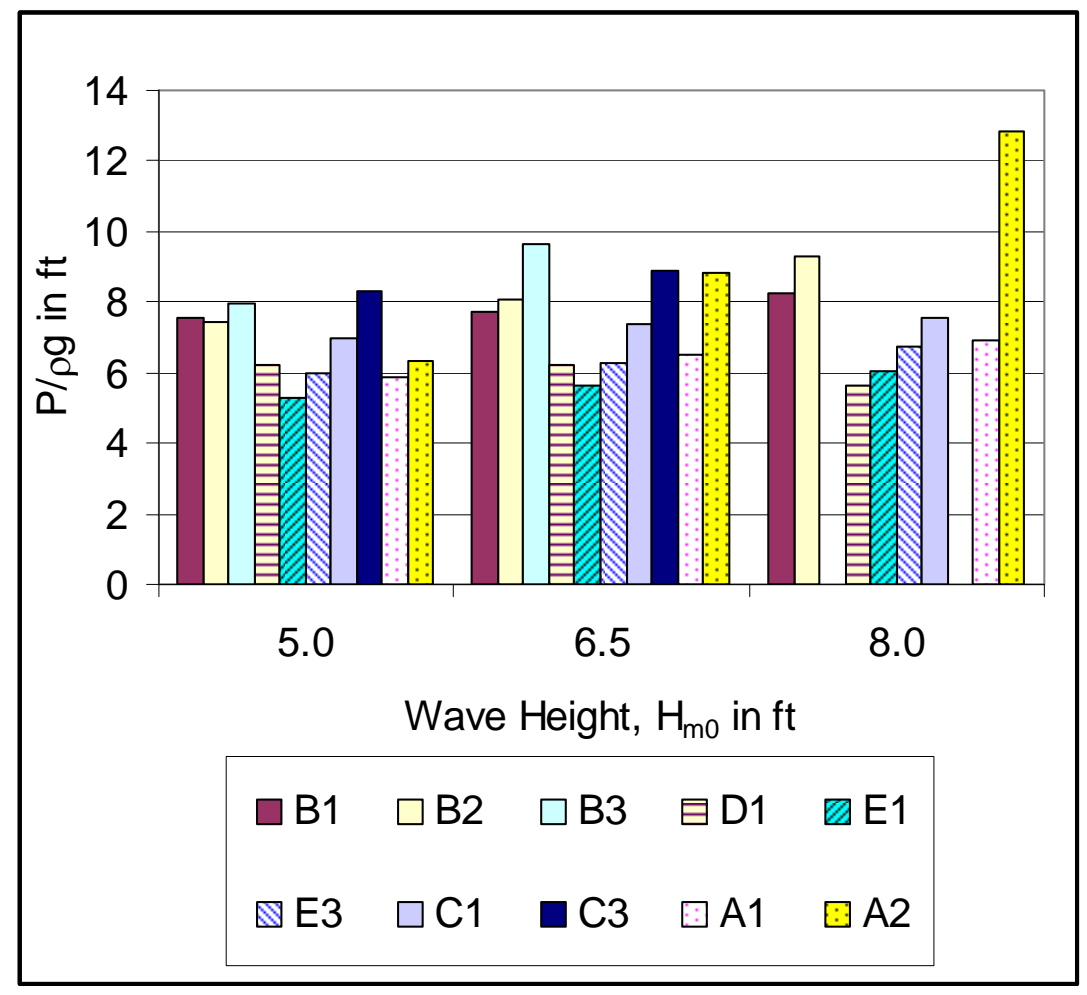

Figure 39. Maximum RANS pressures, $T p=4.8 \mathrm{sec}$.

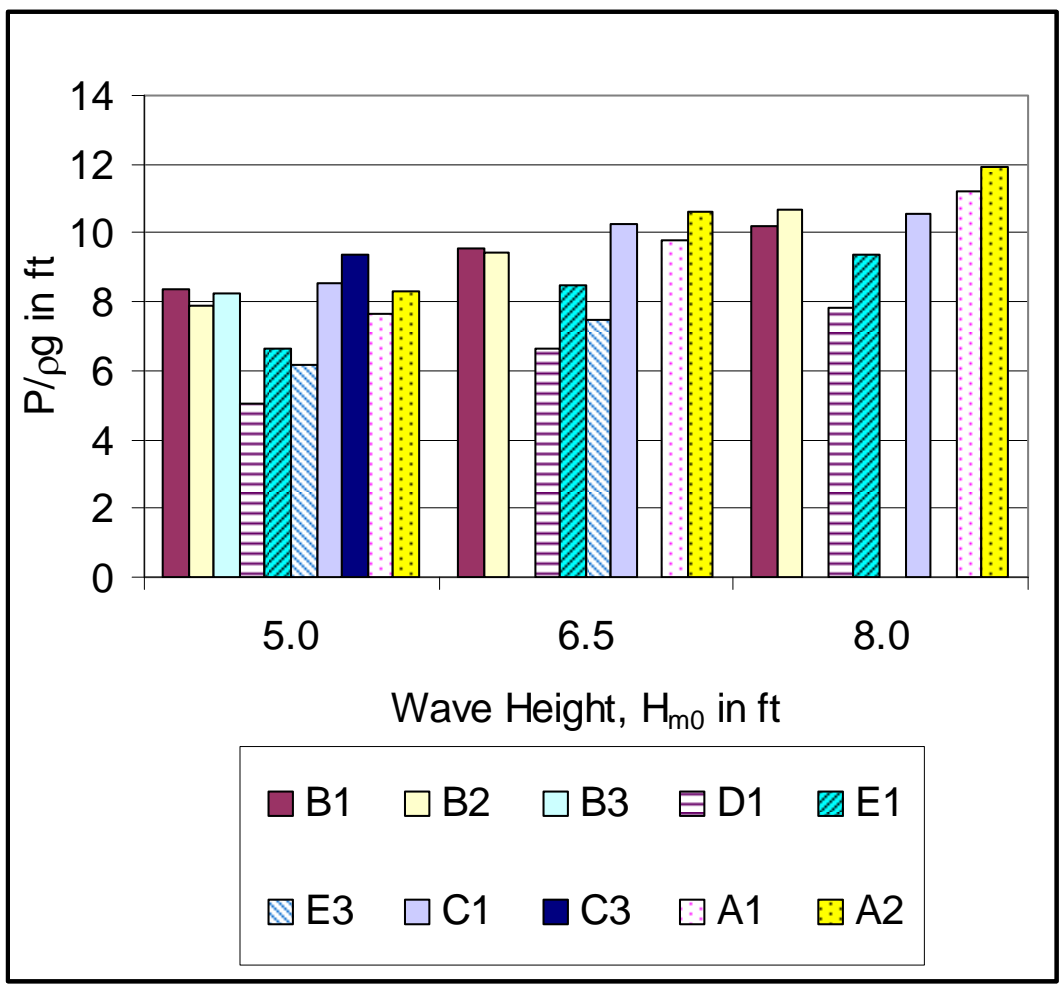

Figure 40. Maximum RANS pressures, $T_{p}=6.7 \mathrm{sec}$. 
The fact that pressure does not always increase with wave height is likely the result of the sensitivity of the maximum pressures to the shape of individual breaking waves and the interaction of the incident breaking wave with the reflected chaotic bore. Observations of individual waves and associated maximum pressures suggested that maximum pressures were often the result of unique wave-structure interactions. Minor variations in successive waves could produce much higher pressures due to details of the incident wave interacting with the rundown from the previous wave and the structure. So, it seems reasonable to assume that the extreme pressure head produced by the A2 section of $P / \rho g=12.8 \mathrm{ft}$ may be possible for the other sections for some unique wave and water level combination. Developing a generalized predictive formula for maximum wave pressures was not possible within the scope of this site-specific project. For project design, it is recommended that the maximum pressures for Section A2 be used. A reasonably conservative representation of the pressure is a linear distribution with maximum pressure head of $P / \rho g=12.8 \mathrm{ft}$ at the berm decreasing to $1 \mathrm{ft}$ on the crest. Below the berm, the pressure head decrease from a maximum of $12.8 \mathrm{ft}$ can be computed reasonably accurately using linear wave theory. 


\section{Structure Cross-Section Optimization}

For this structure, the geotechnical investigation is yet to be completed. As such, a full optimization cannot be done. In this section, we assume that the cost of the embankment is dominated by the cost of the concrete slab. Therefore, it is desirable to minimize the volume of the concrete slab. We also assume that the slab is of uniform thickness. An equation idealistically expressing the volume of the slab can be expressed as

$$
V \approx t w\left(l_{\text {crest }}+l_{\text {berm }}+l_{\text {step }}+l_{\text {slope }}\right)
$$

where

$t=$ slab thickness

$w=$ width of section alongslope

$l_{\text {crest }}=$ length of the crest section

$l_{\text {berm }}=$ length of the berm section

$l_{\text {step }}=$ length of the step section

$l_{\text {slope }}=$ length of the seaward slope section

If we express each slope length by meaningful engineering quantities, Equation 7 becomes

$$
\frac{V}{t w} \approx l_{\text {crest }}+l_{\text {berm }}+\left(R_{c}+h\right)(1+\tan \alpha)
$$

where $\alpha$ is the approximate slope of the seaward slope and step sections. In this case, $1+\tan \alpha=1.33$. Equation 8 can be thought of as representative of a characteristic structure section length. The goal is to minimize the slab volume. The freeboard, $R_{c}$, is computed using Equation 5 to achieve the target overtopping rate for a range of berm widths, $l_{\text {berm }}$, berm depths, $d_{B}$, and water depths, $h$. The range of parameters is as follows.

Wave Height: $H_{m o}=8 \mathrm{ft}$

Wave Period: $T_{p}=6.7 \mathrm{sec}$

Water Depth: $h=13-25 \mathrm{ft}$

Berm Depth: $d_{B}=(-3)-17 \mathrm{ft}$ ( $3 \mathrm{ft}$ above swl to $17 \mathrm{ft}$ below)

Berm Width: $l_{\text {berm }}=0-40 \mathrm{ft}$ 
Crest Width: $l_{\text {crest }}=14 \mathrm{ft}$

Target Overtopping Rate: $0.005 \mathrm{ft} 3 / \mathrm{sec} / \mathrm{ft}$

Figures 41 and 42 illustrate the contributions of the berm width and the width of the seaward slope and step sections, respectively, to the slab volume as a function of the variable berm depth and toe water depth. In addition, the influence of the freeboard and step section height along with the berm width is illustrated in Figures $43-44$. These figures illustrate that the minimum volume with respect to overtopping will always be the structure without a berm. In other words, raising the structure crest is more efficient than increasing the width seaward. Figure 41 also shows that volume increases with increasing depth over the berm. So if a berm is employed, the berm elevation should be located close to the average storm water level in order to maximize the overtopping reduction.

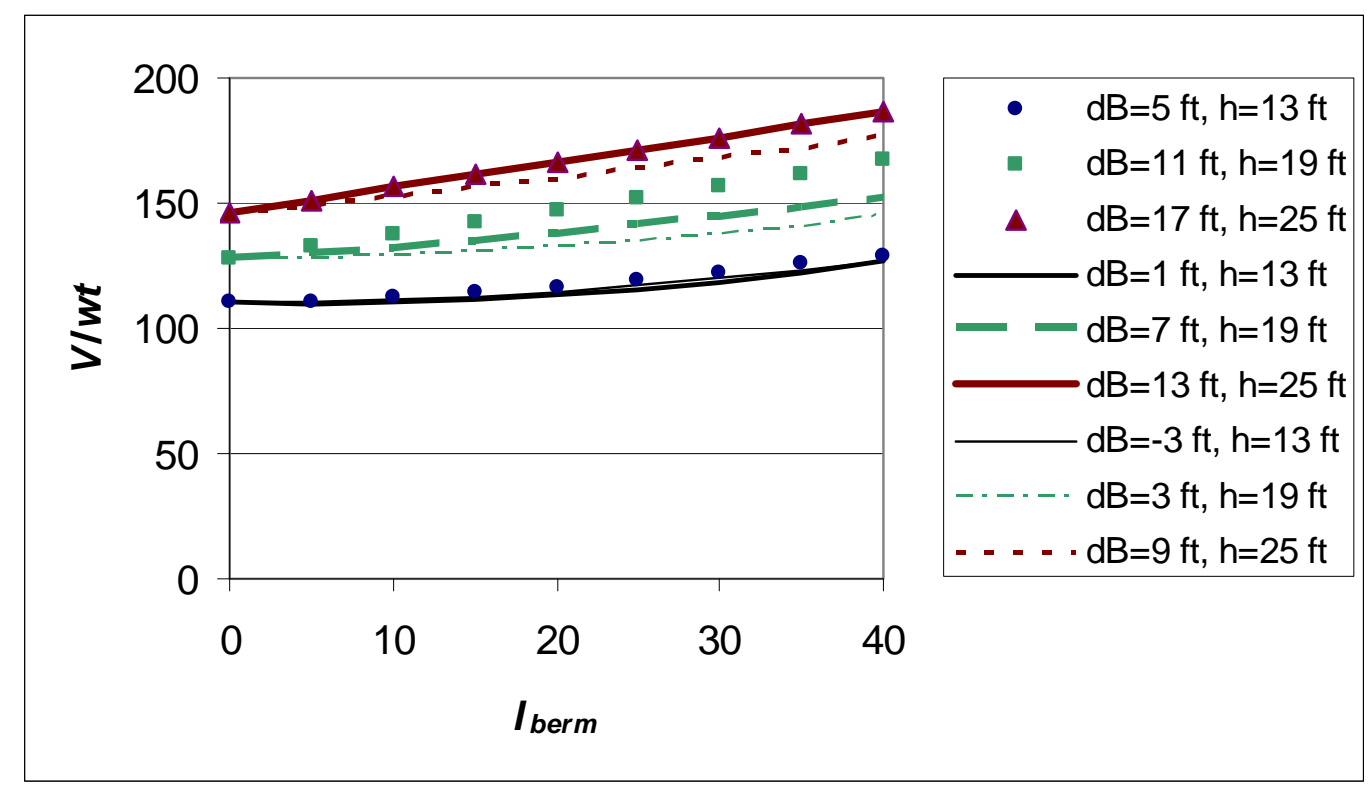

Figure 41. Contribution of berm crest width to slab volume for various berm depths and toe water depths. 


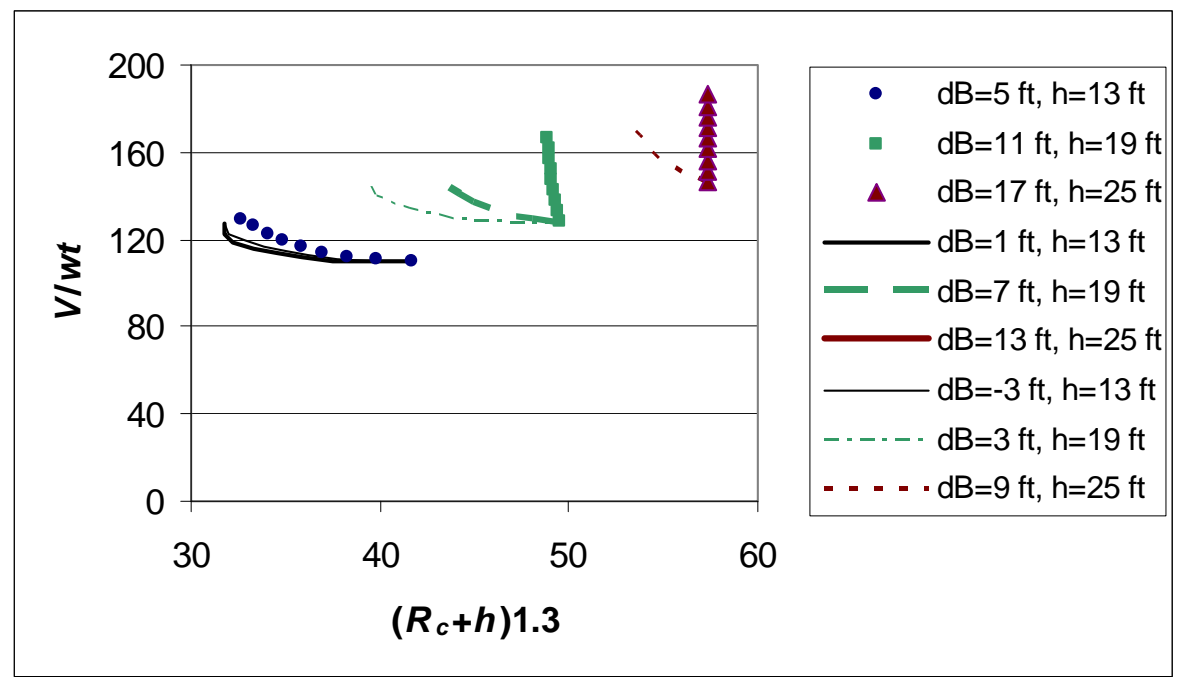

Figure 42. Contribution of step and seaward slope width to slab volume for various berm depths and toe water depths.

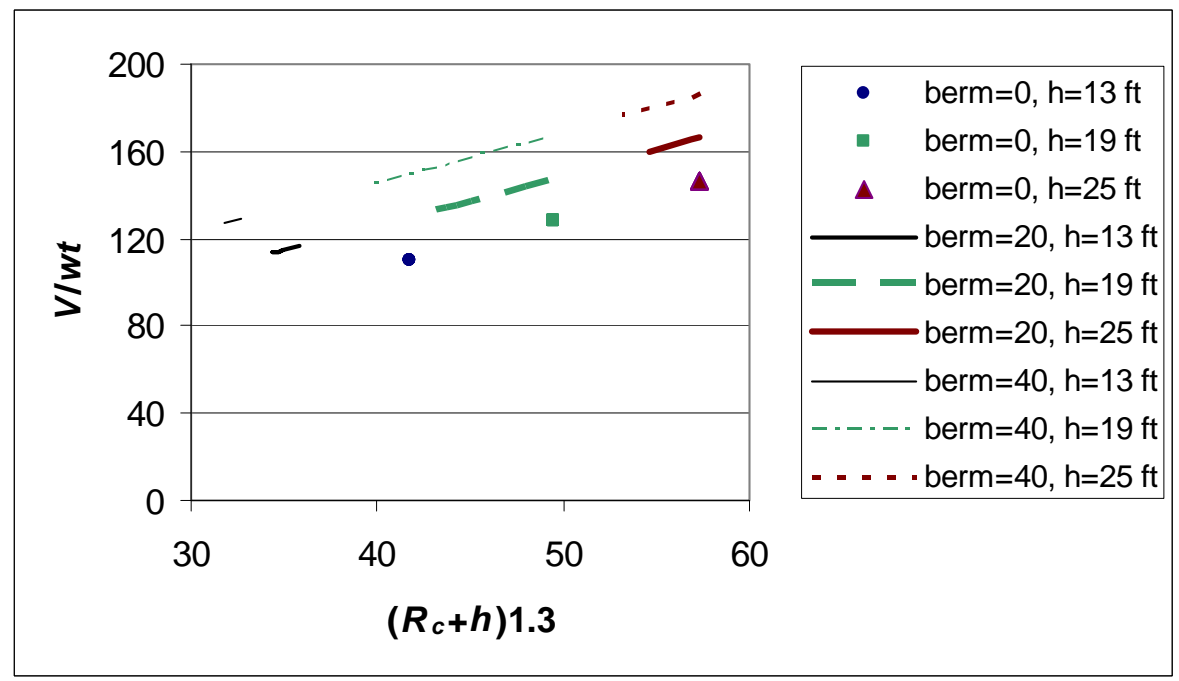

Figure 43. Contribution of step and slope section width to slab volume for various berm widths and toe water depths. 


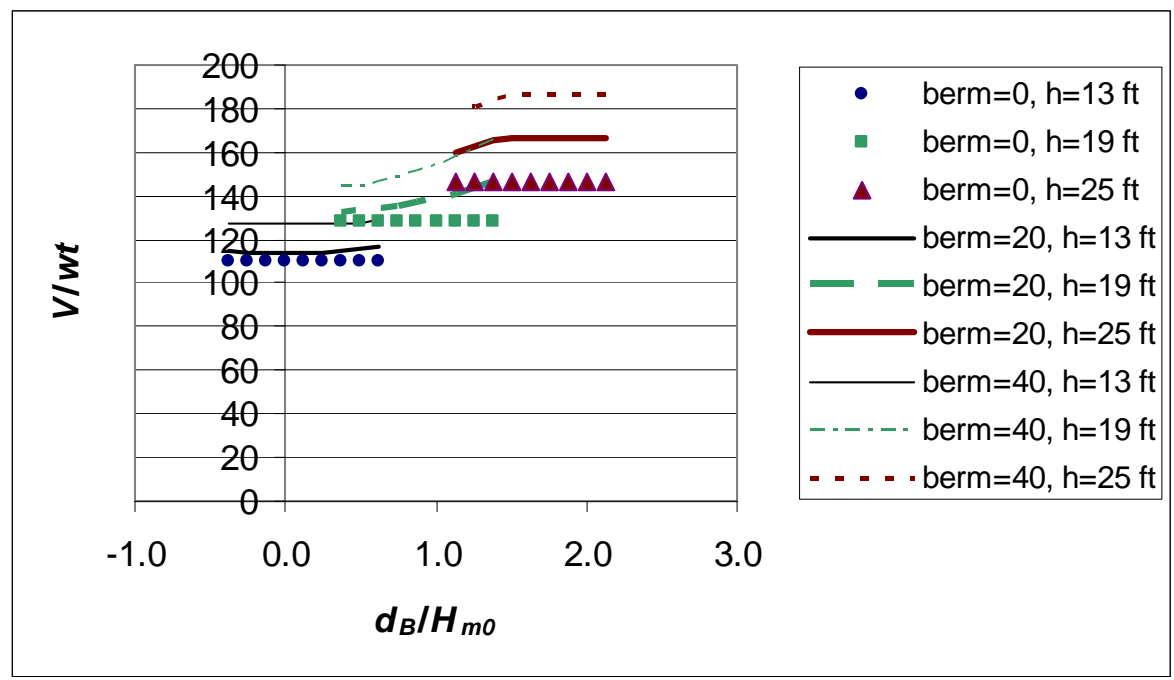

Figure 44. Slab volume as a function of normalized berm depth.

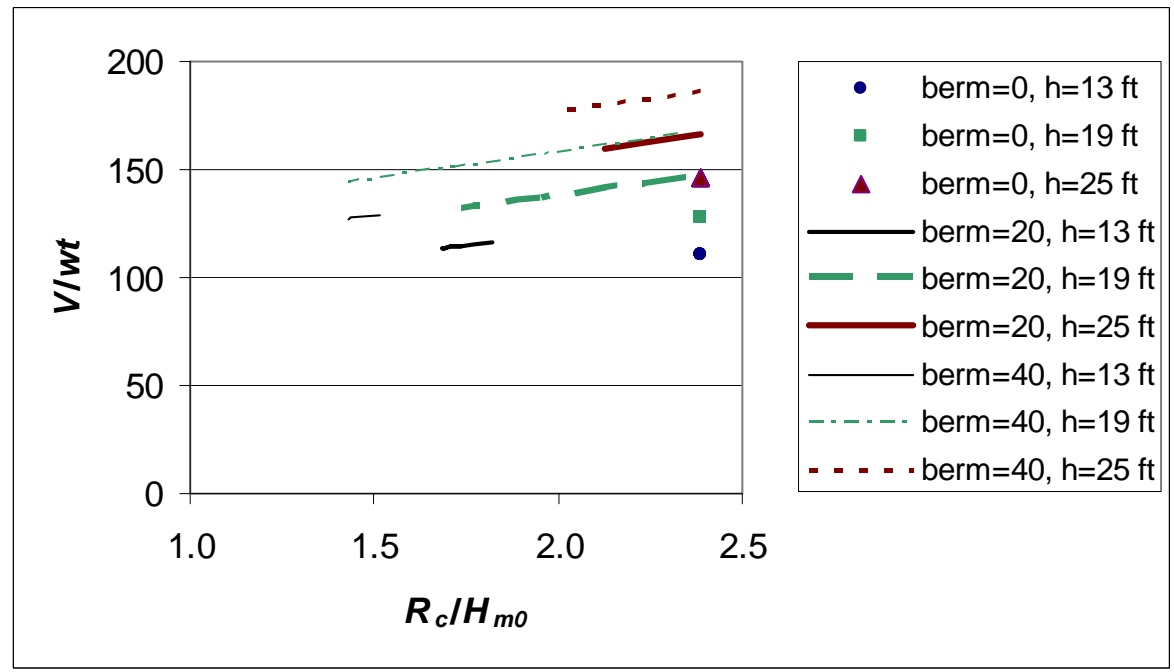

Figure 45. Slab volume as a function of normalized crest freeboard.

The other factor influencing structure volume is the design stress level. The assumption in this section is that the target design stress is a constant and is dictated by the strength of commonly used roller-compacted concrete. The overall slab volume can be described by a simplified relation that addresses the fact that, in order to maintain maximum slab stresses below a constant target design value, the slab volume must increase to compensate for higher fluid pressure loads. The maximum stress will be roughly proportional to the maximum moment in the slab and inversely proportional to the slab thickness squared. The maximum moment will be proportional to the locally maximum pressure load for a uniformly supported slab. So the increase in slab thickness is roughly proportional to 
the square root of maximum pressure. The maximum pressure was shown to be generally higher for the stepped structure without a berm than for the sections with berms. The berms are expected to reduce the impact pressures of the waves and that was the case for this study. However, a conservative design would assume that the most extreme pressures measured in section A2 are possible for all cross-sections for some wave and water level combination. Therefore, the maximum pressure for design is independent of cross-section geometry and the minimum berm width dominates the volume optimization. Note that the minimum slab thickness will depend on the details of the structural design but should refine the berm width selection. 


\section{Conclusions and Recommendations}

The study discussed herein was conducted to assist with the development of design criteria for a stepped embankment cross-section. The structure is intended to comprise the perimeter of a water supply basin. The crosssection designs incorporate a berm with a stair-stepped face and a wide crest and will likely be built using roller compacted concrete. Physical and numerical models were developed to measure overtopping rates for varied structure cross-sections and varied wave and water level conditions. The primary goal was to determine structure crest heights that met the target overtopping rate of $0.005 \mathrm{ft} 3 / \mathrm{sec} / \mathrm{ft}$ for a range of parametric permutations. Physical model wave overtopping data were used to calibrate a generalized predictive empirical overtopping equation. In addition, wave pressures on the embankment face were measured in order to assist with structural design of the roller-compacted concrete face of the embankment.

Based on the observations from tests with $13 \mathrm{ft}$ toe water depth, a $40.0 \mathrm{ft}$ wide berm at water depth $-2.5 \mathrm{ft}$ below swl resulted in the lowest respective crest elevation. For $19 \mathrm{ft}$ toe water depth, two classes of crosssections were tested. For this depth, the $25.0 \mathrm{ft}$ wide berm (B2) required less freeboard to reach the target overtopping than the section with no berm (A2). At toe water depth $25.0 \mathrm{ft}$, the most effective cross-section was $\mathrm{C}_{3}$, with a $40.0 \mathrm{ft}$ wide berm at depth $5.0 \mathrm{ft}$. Generally, wider berms produced lower required crest heights, as expected. Also, berm elevations near the swl produced more efficient cross-sections with respect to wave overtopping.

Existing predictive empirical overtopping equations were compared to lab data to determine applicability to these unique design embankments. The equations were found to produce fairly large errors and to not describe the variability of the data well. A predictive overtopping equation was fit to physical model data (Equations 1-3). The range of application of the equation for the estimation of overtopping developed during this study is limited to the range of conditions tested as discussed in this report. The equation is useful for optimizing the geometry of the section given design constraints. For example, if it is found that high crest elevations are not acceptable, then the berm can be widened and moved vertically to 
maintain a target level of overtopping. In addition, the effect of smooth slopes is compared to stepped and sporadic block roughness elements. Both the smooth slopes and sporadic blocks allow egress of turtles from the basin. The empirical equations provide a useful tool to evaluate the impacts of using a smoother section than the stepped version.

A new Reynolds-averaged Navier Stokes (RANS) numerical model called COBRAS was incorporated into this study to develop a predictive tool as well as quantify maximum wave pressures on the embankment. The model was run for all of the cases tested within the physical model study. COBRAS appears to be capable of predicting the overtopping rates. Some runs produced differences as large as one order of magnitude. Some of this variability was due to the different realization of waves run in the numerical and physical model. However, it appeared as though numerical instabilities due to the thin water layer on the crest also contributed to some differences. The COBRAS overtopping results will require further examination outside the scope of this study in order to make definitive conclusions on the accuracy. However, for most cases, the model appeared to reasonably predict overtopping rates.

COBRAS was used to determine detailed maximum pressure distributions on the face of the embankment. Comparison with measured pressures for regular waves indicated that COBRAS was surprisingly accurate at predicting the pressure time series on the structure considering the complexity of the hydrodynamics. However, it was noted that the high frequency wave slamming pressures that result from the condition where a collapsing air pocket is trapped between the wave face and the step were not reproduced well by the single-phase RANS model. When both COBRAS and physical model time series were filtered to eliminate the frequencies above the structure response frequencies, then the maximum pressures agreed well. When the pressure on any step was at a maximum, the pressure distribution across the structure was exponentially increasing with increasing depth. However, often the pressure spiked on one or more steps and this was likely a result of complex wave breaking forces. The interaction of the incident breaking wave with the reflected broken bore produced highly chaotic hydrodynamics on the structure berm and this led to large variations in maximum pressure. Maximum pressure also increased with increasing berm depth. This was a result of both increased static head as well as higher wave pressures. The pool depth did not appear to influence the maximum pressures in a predictable way. 
Generally the maximum pressure increased with increasing wave height and was less for narrower berm widths, although there were exceptions. The maximum pressure head of $P / \rho g=12.8 \mathrm{ft}$ occurred on section A2. It was concluded that the extreme pressures could be possible for the other cross sections for some wave and water level conditions that were not examined in this study. So it is prudent to use the maximum pressures measured for design of the slab, regardless of the section chosen.

A simple volumetric optimization was conducted to determine the most effective cross-section. The study showed that the no-berm section was the most efficient. However, this section requires the highest crest level which may be unacceptable for aesthetic or other reasons. Equation 8 and the RANS model can be used to refine the design if further optimization is required. 


\section{References}

Coastal Engineering Manual. 2002. Vicksburg, MS: Coastal and Hydraulics Laboratory, U.S. Army Engineer Research and Development Center.

Hasselmann, K., T. P. Barnett, E. Bouws, H. Carlso, D. C. Cartwright, K. Enke, J. Ewing, H. Gienapp, D. E. Hasselmann, W. Sell, and H. Walden. 1973. Measurements of wind-wave growth and swell decay during the Joint Sea Wave Project JONSWAP). Hamburg, Germany: Deutshes Hydrographisches Institut.

Hsu, T.-J., T. Sakakiyama, and P. L.-F. Liu. 2002. A numerical model for wave motions and turbulence flows in front of a composite breakwater. Coastal Engineering, 461, 25-50.

Lin, P., and P. L.-F. Liu. 1998. A numerical study of breaking waves in the surf zone. J. Fluid Mechanics 359, 239-264.

Pullen T., N. W. H. Allsop, T. Bruce, A. Kortenhaus, H. Schüttrumpf, and J. W. van der Meer. 2007. EurOtop: Wave overtopping of sea defences and related structures: Assessment Manual. www.overtopping-manual.com. 


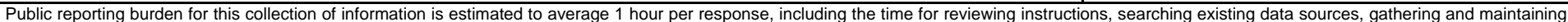

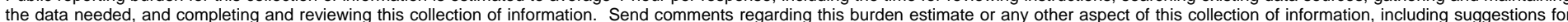

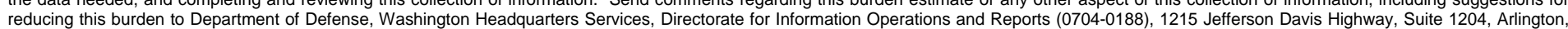

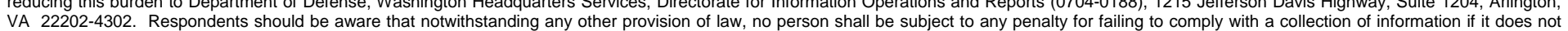
VA 22202-4302. Respondents should be aware that notwithstanding any other provision of law, no person shall be sube
display a currently valid OMB control number. PLEASE DO NOT RETURN YOUR FORM TO THE ABOVE ADDRESS.
1. REPORT DATE $(D D-M M-Y Y Y Y)$ 2. REPORT TYPE 15-04-2009 Final

4. TITLE AND SUBTITLE

South Forida Reservoir Embankment Study

3. DATES COVERED (From - To)

5a. CONTRACT NUMBER

5b. GRANT NUMBER

5c. PROGRAM ELEMENT NUMBER

6. AUTHOR(S)

Jeffry A. Melby, Elizabeth C. Burg, Darla McVan and William Henderson

5d. PROJECT NUMBER

5e. TASK NUMBER

5f. WORK UNIT NUMBER

7. PERFORMING ORGANIZATION NAME(S) AND ADDRESS(ES)

8. PERFORMING ORGANIZATION REPORT NUMBER

Coastal and Hydraulics Laboratory

U.S. Army Engineer Research and Development Center

ERDC/CHL TR-09-3

3909 Halls Ferry Road

Vicksburg, MS 39180-6199

9. SPONSORING I MONITORING AGENCY NAME(S) AND ADDRESS(ES)

10. SPONSOR/MONITOR'S ACRONYM(S)

U.S. Army Engineer District

701 San Marco Boulevard

Jacksonville, Fl 32207-0019

11. SPONSOR/MONITOR'S REPORT NUMBER(S)

\section{DISTRIBUTION I AVAILABILITY STATEMENT}

Approved for public release; distribution is unlimited

\section{SUPPLEMENTARY NOTES}

\section{ABSTRACT}

As part of the Comprehensive Everglades Restoration Project (CERP), the Jacksonville District of the US Army Corps of Engineers is designing an impoundment embankment cross-section. The structure is intended to comprise the perimeter of a water supply basin. The conceptual cross-sections feature interior step and berm embankment faces to armor the containment levee, reduce wave overtopping to acceptable levels, and control reflected wave energy. The goal of the study was to develop engi-neering guidance for optimizing the structure cross-section to provide the minimum structure that met both wave overtopping and wave pressure design criteria. A smallscale physical model study of waves impacting and overtopping the embankment was conducted. A parallel effort was also completed using the COBRAS numerical model based on the Reynolds-averaged Navier Stokes (RANS) equations. The COBRAS model was shown to predict both wave overtopping and hydraulic pressures on the embankment well. An empirical equation was developed to predict wave overtopping as a function of structure configuration and wave and water level conditions. The study concluded that the stepped structure with no berm was optimal at reducing overtopping. The structure with continuous steps inhibits turtle egress from the basin. Therefore, guidance is provided for smooth slopes as well as for slopes employing separated blocks for overtopping reduction. The maximum pressures were shown to vary un-predictably with increasing berm width and depth. The maximum pressure was generally higher for the stepped structure without a berm than for the sections with berms. The highest pressures on the embankment appeared to be more a function of the details of the breaking wave interacting with the structure face than the structure geometry.

\begin{tabular}{|c|c|c|c|c|c|}
\hline \multicolumn{2}{|l|}{ 15. SUBJECT TERMS } & \multicolumn{2}{|l|}{ Waves } & \multicolumn{2}{|c|}{ Pressure } \\
\hline \multicolumn{2}{|l|}{ Embankment } & \multicolumn{2}{|l|}{ Berm } & \multicolumn{2}{|c|}{ RANS } \\
\hline \multicolumn{2}{|l|}{ Levee } & Overtopping & \multicolumn{3}{|c|}{ Physical Model } \\
\hline \multicolumn{3}{|c|}{ 16. SECURITY CLASSIFICATION OF: } & $\begin{array}{l}\text { 17. LIMITATION } \\
\text { OF ABSTRACT }\end{array}$ & $\begin{array}{l}\text { 18. NUMBER } \\
\text { OF PAGES }\end{array}$ & $\begin{array}{l}\text { 19a. NAME OF RESPONSIBLE } \\
\text { PERSON }\end{array}$ \\
\hline $\begin{array}{l}\text { a. REPORT } \\
\text { UNCLASSIFIED }\end{array}$ & $\begin{array}{l}\text { b. ABSTRACT } \\
\text { UNCLASSIFIED }\end{array}$ & $\begin{array}{l}\text { c. THIS PAGE } \\
\text { UNCLASSIFIED }\end{array}$ & & & $\begin{array}{l}\text { 19b. TELEPHONE NUMBER (include } \\
\text { area code) }\end{array}$ \\
\hline
\end{tabular}

